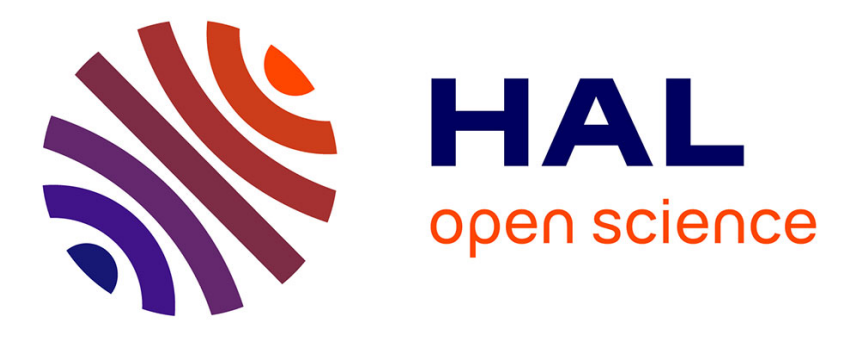

\title{
Perceptions of climate change and adaptation: A subarctic archipelago perspective (Saint-Pierre-and-Miquelon, North America)
}

Xénia Philippenko, Lydie Goeldner-Gianella, Gonéri Le Cozannet, Delphine Grancher, Ywenn de La Torre

\section{To cite this version:}

Xénia Philippenko, Lydie Goeldner-Gianella, Gonéri Le Cozannet, Delphine Grancher, Ywenn de La Torre. Perceptions of climate change and adaptation: A subarctic archipelago perspective (SaintPierre-and-Miquelon, North America). Ocean and Coastal Management, 2021, 215, pp.105924. 10.1016/j.ocecoaman.2021.105924 . hal-03420869

\section{HAL Id: hal-03420869 https://hal.science/hal-03420869}

Submitted on 18 Nov 2021

HAL is a multi-disciplinary open access archive for the deposit and dissemination of scientific research documents, whether they are published or not. The documents may come from teaching and research institutions in France or abroad, or from public or private research centers.
L'archive ouverte pluridisciplinaire HAL, est destinée au dépôt et à la diffusion de documents scientifiques de niveau recherche, publiés ou non, émanant des établissements d'enseignement et de recherche français ou étrangers, des laboratoires publics ou privés. 


\title{
Perceptions of climate change and adaptation: A subarctic archipelago perspective (Saint-Pierre-and-Miquelon, North America)
}

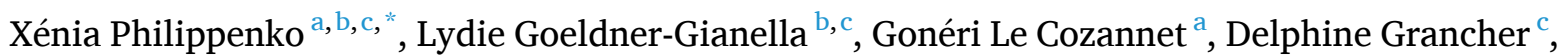 \\ Ywenn De La Torre ${ }^{\mathrm{d}}$
}

${ }^{\text {a }}$ French Geological Survey (BRGM), 3 Avenue Claude Guillemin, 45060, Orléans, Cedex 2, France

${ }^{\mathrm{b}}$ University Paris 1 Panthéon-Sorbonne, Institute of Geography, 191 Rue Saint-Jacques, 75005, Paris, France

${ }^{\mathrm{c}}$ Laboratory of Physical Geography UMR 8591, 1 Place Aristide Briand, 92195, Meudon, France

${ }^{\mathrm{d}}$ French Geological Survey (BRGM), Regional Direction Guadeloupe, Parc D'activités de Colin - La Lézarde, 97170, Petit-Bourg, Guadeloupe, France

\section{A R T I C L E I N F O}

\section{Keywords:}

Adaptation to climate change

Social acceptance

Perceptions

Coastal risks

Subarctic community

\begin{abstract}
A B S T R A C T
Climate change is projected to challenge adaptation capacity in small islands worldwide due to rising temperatures, sea-level rise, extreme events and changing rainfall patterns. However, adaptation planning and implementation may be delayed where people perceive a lack of urgency and put forward competing priorities such as economic development. Here, we assess perceptions of climate change and adaptation in Saint-Pierre-andMiquelon, a subarctic archipelago located south of Newfoundland, Canada. We performed and analysed a social survey reaching 289 individuals out of a population of 6260, through a questionnaire conducted both faceto-face and online. We show that inhabitants of Saint-Pierre-and-Miquelon generally have a clear understanding of climate change and perceive adaptation as urgent for a number of vulnerable coastal sites. Despite some disagreements on adaptation options and the timing for implementation, it is noteworthy that even relocation action is mentioned and sometimes requested. We show that perceptions of climate change and of adaptation within Saint-Pierre-and-Miquelon are heavily influenced by place attachment, personal experience of coastal hazards and environmental awareness. From a methodological point of view, our results highlight the relevance of using online surveys in well-connected but geographically isolated communities. From an adaptation perspective, our results suggest that people's perceptions and beliefs are not only a barrier, but rather offer in some cases opportunities for adaptation planning and implementation. Such favourable attitudes toward adaptation do not exist across all small islands, so our results may be useful in determining the conditions under which people's perceptions are conducive to adaptation.
\end{abstract}

\section{Introduction}

Erosion risk and coastal flooding are projected to increase worldwide due to climate change (Wong et al., 2014; Collins et al., 2019). On the one hand, coastal zones are affected by sea-level rise (Oppenheimer et al., 2019) while on the other hand, their attractiveness has increased over the last century due to coastal tourism, economic vitality, attractive living environment and urban sprawl (Neumann et al., 2015). Small islands are considered particularly vulnerable to the effects of climate change on environment, ecosystems, human settlements, societies and economies, with varying levels of vulnerability depending on their context and specificities (Nurse et al., 2014; Magnan et al., 2019; Petzold and Magnan, 2019). It is now widely acknowledged that planned adaptation is required to address future coastal risks induced by climate change (Mimura et al., 2014; Noble et al., 2014). A growing number of countries have adopted national adaptation strategies (Biesbroek et al., 2010). However, adaptation initiatives are not always successful and may fail without appropriate consideration of social barriers, among other barriers (Adger et al., 2009; Eisenack et al., 2014; Waters et al., 2014). The social acceptance of adaptation solutions is a particularly important issue. This notion is still emerging (Fournis and Fortin, 2015): it concerns the process, in which a social group admits the existence of restrictions in its usual environment, thus reflecting "an ability to accept - without necessarily total integration or adherence" (Depraz and Laslaz,

\footnotetext{
* Corresponding author. French Geological Survey (BRGM), 3 avenue Claude Guillemin, 45060, Orléans, Cedex 2, France.

E-mail addresses: x.philippenko-crnokrak@brgm.fr (X. Philippenko), lydie.goeldner-gianella@univ-paris1.fr (L. Goeldner-Gianella), g.lecozannet@brgm.fr (G. Le Cozannet), delphine.grancher@lgp.cnrs.fr (D. Grancher), y.delatorre@brgm.fr (Y. De La Torre).
} 
2017). Social acceptance depends on multiple factors, such as the perceptions of adaptation solutions or trust in public actors or in governance decisions (Cash et al., 2003; Raufflet, 2014; Fournis and Fortin, 2015; Rey-Valette et al., 2019).

Previous studies have shown that understanding individual and community level perceptions helps understand people's attitudes toward coastal risks and climate change and assess acceptance of adaptation policies (Renn, 1998; Costas et al., 2015; Minéo-Kleiner, 2017). The term "perception" has been defined in various way in the literature, we define it here as follows: perception is a form of information processing during which the automatic tasks related to sensory reflexes go together with more controlled tasks related to cognitive activity (Riviere-Honegger et al., 2015). This goes beyond physically experiencing a storm, feeling wind or noticing erosion on a coast, as our pre-existing cognitive models (our knowledge, experiences, aspirations, etc.) are called on to interpret these sensory data. Thus perceptions are not just the way we experience the world through our five senses, but also the lens through which we understand those experiences and values we attribute to them. These individual mental perceptions become social perceptions once they consist of " a form of socially elaborated and shared knowledge [...] contributing to the construction of a reality common to a social whole" (Jodelet, 2003). As an example, we can mention the case of French Polynesia where a social perception currently shared by the population is that climate change is rather a problem than a danger (Goeldner-Gianella et al., 2019). Most of the studies on perceptions either focused on coastal areas characterized by high population density and important issues at stake (Carlton and Jacobson, 2013), or on small tropical islands or atolls (Lata and Nunn, 2012; Nurse et al., 2014; Goeldner-Gianella et al., 2015; Magnan et al., 2019). Subarctic islands are characterized by highly specific challenges: they are subject to different physical processes than tropical small islands, such as decreasing sea ice and snow cover, a rapid change of biodiversity or

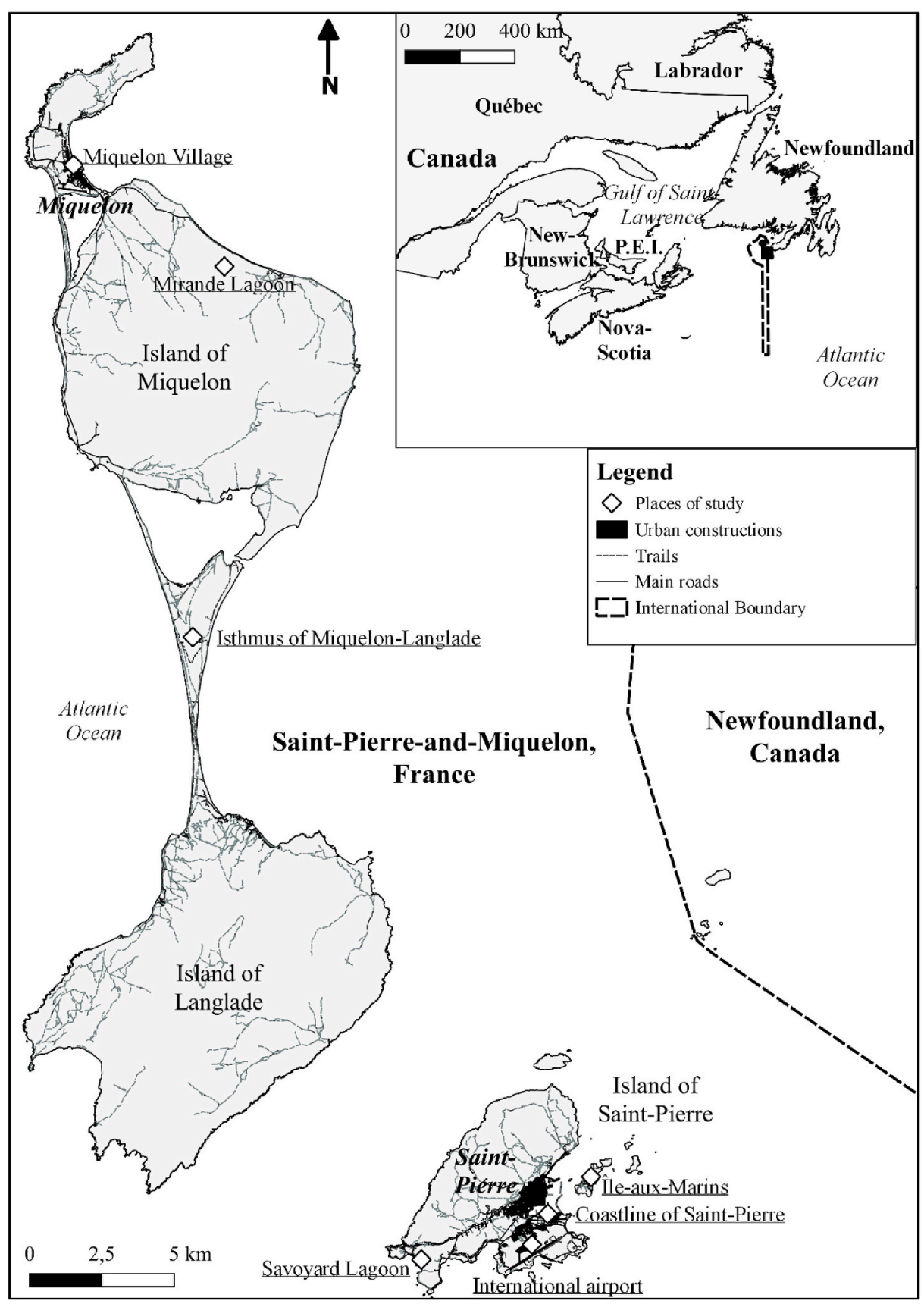

Fig. 1. A. Location of Saint-Pierre-and-Miquelon. B. The archipelago of Saint-Pierre-and-Miquelon. 
shoreline erosion (Larsen et al., 2014; Meredith et al., 2019; Magnan et al., 2019). Unlike high-density regions, holding the shoreline is not the only option (Circé et al., 2016; Creach et al., 2020), and there are social dilemmas involved in using the limited resources available for adaptation. Only a few studies have addressed subarctic regions and islands, and most of them focus on traditional societies, whose subsistence is based on hunting and fishing (Canosa et al., 2020). Climate change will indeed induce strong challenges in these traditional communities, reducing the availability of subsistence resources or threatening the traditional way of life (Brinkman et al., 2016; Herman-Mercer et al., 2016). However, adaptation is not limited to indigenous societies, especially because subarctic societies are increasingly westernized.

Here, we contribute to knowledge on adaptation in these subarctic islands by analysing perceptions of climate change and of adaptation measures in Saint-Pierre-and-Miquelon, a small subarctic French archipelago in the Western North Atlantic. Specifically, we investigate the drivers of different perceptions of climate change and adaptation in this subarctic territory. We also discuss the methodological aspects of conducting a survey both online and face-to-face for environmental and island studies.

After describing our study's context and methods [Sections 2 and 3], the paper assesses the perceptions of climate change, then the perceptions of various solutions at different scales and their drivers [Section 4]. It then discusses the overall results and their meaning for managing coastal adaptation to climate change in the subarctic islands of SaintPierre-and-Miquelon [Section 5].

\section{Physical and human context}

Saint-Pierre-and-Miquelon is a French Overseas Territory located in the Western North Atlantic, $25 \mathrm{~km}$ from the Burin Peninsula of Newfoundland [Fig. 1]. The total population stood at 6260 inhabitants in 2018 (INSEE, 2019 census), with more than $89 \%$ of that total living on the smaller island of Saint Pierre. Saint-Pierre-and-Miquelon is a French "Overseas Collectivity", which has a semi-independent institutional status, granting local autonomy on taxes, customs and urbanism laws.

When French fishers first arrived at the beginning of the 16th century, there were no indigenous people living on the islands. Cod fisheries were the archipelago's primary resource from the 16th century to the early 20th century. After the Second World War, the islands mostly supplied cod trawlers in the Grand Banks (Cermakian et al., 1970). In 1992, the fishery activities came to a complete end in Saint-Pierre-and-Miquelon, due to an international court decision to reduce the perimeter of the archipelago's Exclusive Economic Zone and to the moratorium on the cod resources designed to prevent overfishing. These two events triggered an economic crisis in Saint-Pierre-and-Miquelon, from which the archipelago has not really recovered. Today, half the population works in administration, education or health, and $37 \%$ in tourism, business, transport or various services (IEDOM, 2017). As a consequence, a growing part of the population now originates from mainland France, having come here for three years on average to work in the public services (Le Gléau and Castaing, 2000). Hereafter residents who are the descendants of European fishermen who settled between the 17th and 19th centuries will be referred to as 'Native' to Saint-Pierre-and-Miquelon. Importantly, natives and newcomers from the mainland do not always share the same vision about ways of life and development of the archipelago. Concurrently, the population is declining, and moreover the young generation is leaving the archipelago to study and work outside Saint-Pierre-and-Miquelon, either in France or in French-speaking Canada.

The archipelago includes three main islands: Saint-Pierre, Miquelon and Langlade, the latter two being connected by a double tombolo (Billy et al., 2015). Altitudes in Saint-Pierre-and-Miquelon do not exceed 240 $\mathrm{m}$. The climate is subarctic and the total area is about $242 \mathrm{~km}^{2}$, with a coastline of approximatively $200 \mathrm{~km}$ (De La Torre et al., 2013), that faces two kinds of major hazard: coastal erosion and flooding, both exacerbated by storms. Rocky coastlines represent $64 \%$, accumulation coastlines $28 \%$, and artificialized coastlines only $8 \%$ (De La Torre et al., 2013). A part of the rocky coastline is morainic and therefore highly erodible. The climate of Saint-Pierre-and-Miquelon is characterized by heavy rainfall, frequent fogs and windy conditions. High wind-speeds are frequent, with a maximum speed of $230 \mathrm{~km} / \mathrm{h}$ in 2009 (based on data from the French National Weather Survey: http://www.meteospm. org). Local extreme floods events with damage seem to be a recent phenomenon, based on local reports: a coastal flooding event in the town of Saint-Pierre in 1982; three storms in 2009, 2016 and 2021 with damage to the road on the Miquelon-Langlade isthmus; flooding in Miquelon village in 2018. Seven areas are identified by scientists and local managers as the most vulnerable in Saint-Pierre-and-Miquelon, due to both environmental and anthropogenic factors (De La Torre et al., 2013): three on Miquelon Island, four on Saint Pierre Island [Figs. 1 and 2]. The Île-aux-Marins (Island of Sailors) is locally an important historical and cultural place, with no permanent settlements, lying at very low altitude opposite the town of Saint-Pierre [Fig. 2A]. The Etang de Savoyard (Savoyard Lagoon) is a leisure area, separated from the sea by a very thin beach barrier [Fig. 2B]. The coastline of Saint-Pierre town is home to the archipelago's urban hub with its's administrative, economic, and health services. Most of the infrastructure are located on the seafront and protected by harbour walls [Fig. 2C]. The international airport provides the link with the rest of the world, for communications, the economy and for health emergencies. It is located on a low-lying area, protected by an earthen dyke [Fig. 2D]. The village of Miquelon is located on a low-lying area and is surrounded by the sea [Fig. 2E]. The Etang de Mirande (Mirande Lagoon) is a leisure area, hosting a campsite and a few holiday homes. A road, located on the beach barrier, provides the only access, currently protected by rockfill [Fig. 2F]. The isthmus is a recent geological formation (Billy et al., 2015) and, since the 17th century, has connected the island of Miquelon with the island of Langlade, the latter being an area for holiday homes. The isthmus is a leisure area but also an important communication link, since it is crossed by the only road [Fig. 2G].

The current climate and physical contexts are now changing. Canadian and IPCC reports deliver evidence of regional warming in both sea and air temperatures, due to climate change, and projected to continue in the 21st century (Romero-Lankao et al., 2014; Lemmen et al., 2016; Bush and Lemmen, 2019). Extreme temperatures and rainfall are very likely to increase, while snowfall and coastal sea-ice are very likely to decrease (Oppenheimer et al., 2019; Collins et al., 2019; Bush and Lemmen, 2019). This decrease of the coastal ice-foot, which is the part of the shoreline that freezes in winter, thereby protecting the coast from winter erosion (Bush and Lemmen, 2019), is expected to favour winter shoreline erosion, as suggested by recent - but time limited - observations in Saint-Pierre-and-Miquelon (De La Torre et al., 2016; De La Torre, 2021). Generally, coastal hazards are expected to increase (Wong et al., 2014). Climate change may also influence the wind regime. At present, the observations cannot confirm this trend either at a global scale or local scale. However, possible changes in wind regimes are identified as a potential driver of increased high wind-speeds and storm surges (Bush and Lemmen, 2019). The sea-level rise in Saint-Pierre-and-Miquelon results not only from climate change but also from the subsidence induced by the global isostatic adjustment (Billy et al., 2015; Oppenheimer et al., 2019). Therefore, the archipelago is one of the areas the most affected by sea-level rise in North America. Anthropogenic factors are an equally important component of the risks in Saint-Pierre-and-Miquelon: most of the houses and infrastructures are located on low-lying coastal areas. Since 1952, the urban and periurban sprawl along the seashore has increased the exposure and vulnerability of the population and property. In France, adaptation has been increasingly built into the regulations since 2007 (Claude et al., 2015), thus providing a framework to implement measures in each region or municipality. In Saint-Pierre-and-Miquelon, some adaptation measures 
A.

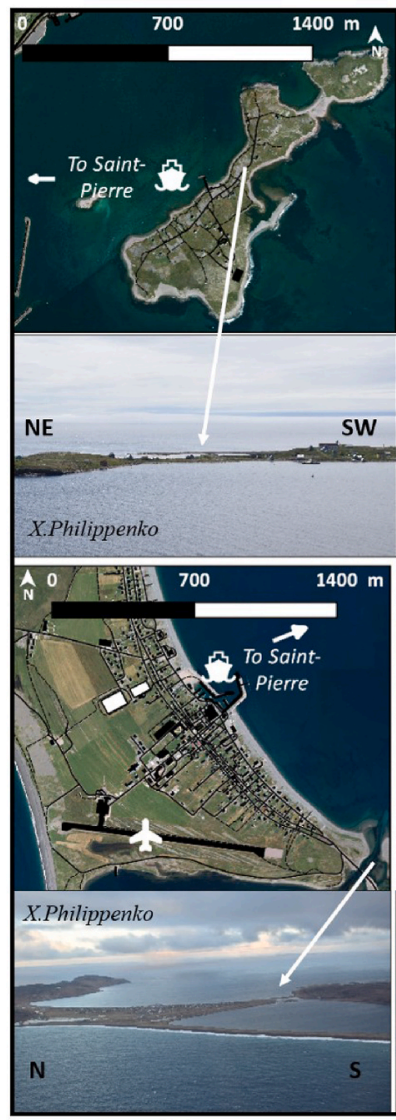

E.
B.
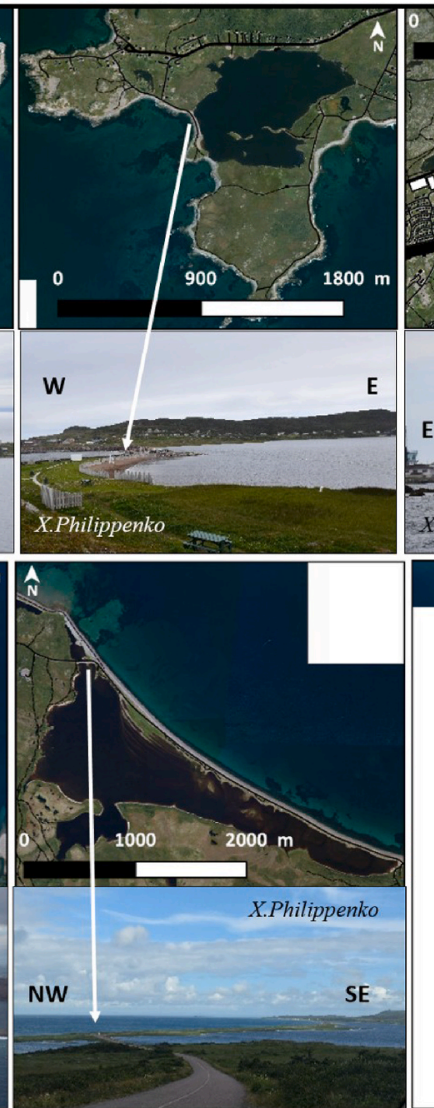

F.
C.

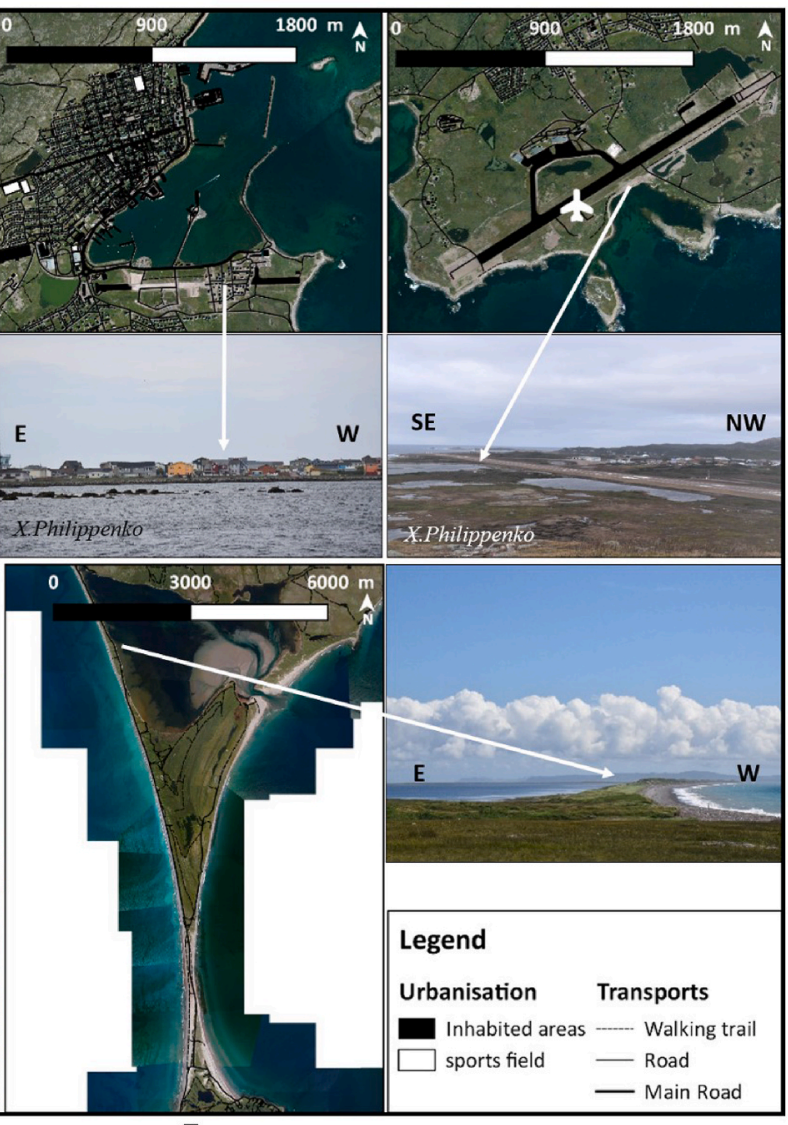

G.

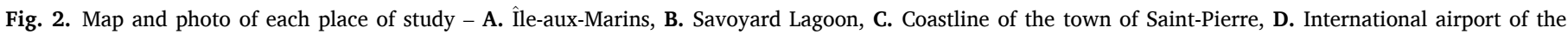

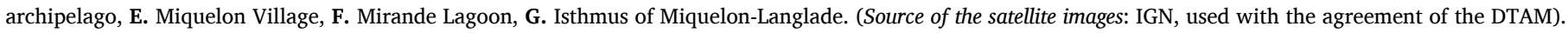

have been implemented since 1990, including the relocation of certain roads on Miquelon-Langlade, along with new coastal defences and soft solutions, such as dune revegetation. Since 2018, a Coastal Risk Prevention Plan (Plan de prévention des risques littoraux - i.e. a national institutional tool) has been approved. This plan creates land-planning constraints based on flood hazard maps considering storms, as well as a sea-level rise scenario of $0.96 \mathrm{~m}$ by 2100 , including $0.26 \mathrm{~m}$ subsidence. Apart from this, no long-term adaptation strategy has so far been established.

\section{Data and methods}

To understand the local perceptions of climate change and of adaptation measures, we used a structured questionnaire applied via two different channels, online and face-to-face. We conducted the face-toface survey with inhabitants from July to September 2019 and the online survey from August to October 2019. The fact that both formats partly take place at the same time allow us to adjust partly the face-toface sample according to the imbalances observed online. The use of two parallel formats was chosen firstly to enlarge our sample and reach different populations and secondly, because the online format allowed us to reach people who were shy or sensitive to social pressure of being seen with someone in the street. The aim was to reduce the self-selection phenomenon for each survey format and to reduce the bias inherent to each mode by drawing on the strength of the other (Frippiat and Marquis, 2010; Dillman et al., 2014). The face-to-face and online questions asked were quite similar overall, differing only on certain points [Table 1]. We removed 32 questions in the online questionnaire in order to ease its reading and reduce the risk of respondents dropping out before completing the survey. We chose to delete mainly less important questions [Appendix A] and in a few rare cases deletions were made for technical reasons; we opened one question in the online questionnaire. We used a map for the face-to-face format to support the storylines associated to each of the seven scenarios. For the online format, we choose to use recent photographs [Fig. 2], in order to visualize the seven locations. The choice to use different images online and face-to-face came from a technical problem: we found that the maps were too small or not resolved enough to identify precisely some locations of interest. The photos used online were only a reminder of the settings of the place of interest, so as not to penalise respondents. Online, we were careful to choose photographs that were as neutral as possible, to reduce as much as possible any biases, showing only the settings of the site (Goeldner-Gianella et al., 2019), and not a process or impacts related to coastal risks (coastal flooding, erosion, etc.). To keep this paper succinct, the differences of methodology and in the responses are described in detail in the Supplementary Materiel - Appendix A to D.

In total, 289 residents (aged between 18 and 75 years old) responded, 140 during the face-to-face survey and 149 via the online survey. This amounts to approximatively $5 \%$ of the archipelago's population. For the face-to-face survey, we selected residents on both islands, randomly, at any time of the day and in various places, such as public services, shops, or on the street. We did not survey tourists, mainly because they do not stay here for very long and therefore, we considered that they were not relevant to our survey. With the exception of this choice, we did not make a strict selection based on demographic or socio-economic criteria. The questionnaire lasted an average $45 \mathrm{~min}$ in both formats. We ran a communication campaign about our online and face-to-face surveys, using a website and a flyer, and by posting regular 
Table 1

Key differences between the online and face-to-face format of the survey.

\begin{tabular}{|c|c|c|c|}
\hline & & Face-to-face format & Online Format \\
\hline \multirow{3}{*}{$\begin{array}{l}\text { Format of } \\
\text { the } \\
\text { survey }\end{array}$} & Length & Full version & $\begin{array}{l}\text { Shortened version ( } 32 \\
\text { deleted questions) }\end{array}$ \\
\hline & $\begin{array}{l}\text { Format of } \\
\text { questions }\end{array}$ & $\begin{array}{l}28 \text { closed-ended } \\
\text { questions with } \\
\text { multiple choice; } 54 \\
\text { closed-ended } \\
\text { questions with } \\
\text { single choice; } 8 \\
\text { open-questions }\end{array}$ & $\begin{array}{l}20 \text { closed-ended } \\
\text { questions with } \\
\text { multiple choice; } 37 \\
\text { closed-ended } \\
\text { questions with single } \\
\text { choice; } 1 \text { open- } \\
\text { question }\end{array}$ \\
\hline & Legal consent & Written approval & Tacit approval \\
\hline \multirow[t]{2}{*}{$\begin{array}{l}\text { Material } \\
\text { support }\end{array}$} & $\begin{array}{l}\text { Choice of } \\
\text { important/ } \\
\text { exposed places } \\
\text { (questions } \mathrm{n}^{\circ} 2 \text { and } \\
\mathrm{n}^{\circ} 30 \text { ) }\end{array}$ & $\begin{array}{l}\text { Choice of places } \\
\text { directly on a map; } \\
\text { spontaneous } \\
\text { responses, items } \\
\text { completed by the } \\
\text { interviewer }\end{array}$ & $\begin{array}{l}\text { Choice of places } \\
\text { between written items } \\
\text { with the support of the } \\
\text { same base as image }\end{array}$ \\
\hline & $\begin{array}{l}\text { Presentation of } \\
\text { scenarios } \\
\text { (question } \mathrm{n}^{\circ} 38 \text { to } \\
\mathrm{n}^{\circ} 58 \text { ) }\end{array}$ & Map & Photographs \\
\hline \multirow[t]{2}{*}{$\begin{array}{l}\text { Potential } \\
\text { biases }\end{array}$} & $\begin{array}{l}\text { Influences biases } \\
\text { linked to the } \\
\text { presence or } \\
\text { absence of the } \\
\text { interviewer }\end{array}$ & $\begin{array}{l}\text { Social desirability } \\
\text { bias related to the } \\
\text { presence of the } \\
\text { researcher; self- } \\
\text { censorship or } \\
\text { refusal due to } \\
\text { insular social } \\
\text { pressure }\end{array}$ & $\begin{array}{l}\text { Weariness caused by } \\
\text { the absence of the } \\
\text { researcher; self- } \\
\text { selection reinforced in } \\
\text { environmental } \\
\text { surveys }\end{array}$ \\
\hline & $\begin{array}{l}\text { Influences biases } \\
\text { linked to the } \\
\text { graphic and } \\
\text { material }\end{array}$ & $\begin{array}{l}\text { Difficulty to read } \\
\text { maps for some kind } \\
\text { of persons }\end{array}$ & $\begin{array}{l}\text { Influence of web } \\
\text { interface graphics and } \\
\text { of visibility of items } \\
\text { on responses; } \\
\text { potential biases linked } \\
\text { to the emotions } \\
\text { photographs provoke }\end{array}$ \\
\hline
\end{tabular}

updates on Facebook and on the local residents' website, where we also added a link to draw wider attention to our online survey.

We structured our questionnaire in five sections: 1) Preliminary questions on the local context and on the level of place attachment, 2) An assessment of the experience and perceptions of current coastal hazards, 3) An assessment of local perceptions of climate change, 4) Identification of perceptions of adaptation and capacity to adapt, 5) Socio-economic characteristics.

In the fourth section, the inhabitants were invited to react to seven adaptation measures at the scale of the archipelago, and to seven scenarios of potential changes for seven local sites [Fig. 2]. We proposed a panel of solutions, from hard to soft solutions, as described in Table 2, distinguishing between solutions according to the level of their economic, technical and ecological impacts (Morris et al., 2018). We categorized relocation as an intermediate solution, because of the ecological and economic cost it induces. The respondents selected their preferred solutions, such as dykes, rockfills, relocation, planting of vegetation or a "do-nothing" strategy [Table 2]. For the face-to-face format, we used a map to support the storylines associated with each of the seven scenarios. For the online format, we choose to use recent photographs [Fig. 2], to visualize the seven locations. This decision to use two different kinds of image - map and photographs - may have induced some biases, which we sought to reduce as much as possible [Appendix D]. Then, as this would have made the online questionnaire too long, only the face-to-face respondents were asked to assess the appropriate time scales by which adaptation to these changes would be required. Participants - mainly online - were able to skip questions: the responses rate therefore varies, depending on the question [Appendix B].
Table 2

Classification of the potential solutions from soft to hard solutions depending on the place of study.

\begin{tabular}{|c|c|c|c|}
\hline Places of study & Soft solutions & $\begin{array}{l}\text { Intermediate } \\
\text { solutions }\end{array}$ & Hard solutions \\
\hline Île-aux-Marins & $\begin{array}{l}\text { - Organize ecological } \\
\text { tour } \\
\text { - Concentrate } \\
\text { tourists visits on a } \\
\text { part of the island } \\
\text { - Abandon and let } \\
\text { the nature do its } \\
\text { work }\end{array}$ & $\begin{array}{l}\text { - Put light fixtures } \\
\text { - Relocate some } \\
\text { houses }\end{array}$ & $\begin{array}{l}\text { - Construct } \\
\text { rockfills } \\
\text { - Build a } \\
\text { seawall }\end{array}$ \\
\hline $\begin{array}{r}\text { Savoyard } \\
\text { Lagoon }\end{array}$ & $\begin{array}{l}\text { - Let the leisure area } \\
\text { in the saline water } \\
\text { of the lagoon } \\
\text { - Abandon the } \\
\text { leisure area and let } \\
\text { the nature do its } \\
\text { work }\end{array}$ & $\begin{array}{l}\text { - Relocate the } \\
\text { leisure area and } \\
\text { accept shoreline } \\
\text { retreat }\end{array}$ & $\begin{array}{l}\text { - Construct } \\
\text { rockfills }\end{array}$ \\
\hline $\begin{array}{l}\text { Coastline of the } \\
\text { town of Saint- } \\
\text { Pierre' }\end{array}$ & $\begin{array}{l}\text { - Limit of } \\
\text { construction in } \\
\text { flooding areas } \\
\text { - Inform and } \\
\text { improve awareness } \\
\text { - Quit the } \\
\text { archipelago } \\
\text { - Do nothing }\end{array}$ & $\begin{array}{l}\text { - Relocate the road } \\
\text { - Relocate some } \\
\text { infrastructures } \\
\text { - Enhance docks, } \\
\text { houses, low walls }\end{array}$ & $\begin{array}{l}\text { - Enhance the } \\
\text { existant } \\
\text { seawall } \\
\text { - Construct } \\
\text { rockfills } \\
\text { - Build a new } \\
\text { seawall }\end{array}$ \\
\hline $\begin{array}{l}\text { International } \\
\text { airport }\end{array}$ & $\begin{array}{l}\text { - Develop boat } \\
\text { connections } \\
\text { - Quit the } \\
\text { archipelago } \\
\text { - Do nothing }\end{array}$ & $\begin{array}{l}\text { - Enhance the } \\
\text { railway } \\
\text { - Relocate the } \\
\text { airport }\end{array}$ & $\begin{array}{l}\text { - Construct } \\
\text { rockfills } \\
\text { - Build a } \\
\text { seawall }\end{array}$ \\
\hline $\begin{array}{c}\text { Miquelon } \\
\text { Village }\end{array}$ & $\begin{array}{l}\text { - Plant some } \\
\text { vegetation } \\
\text { - Put some light } \\
\text { fixtures } \\
\text { - Renonce to the } \\
\text { village }\end{array}$ & $\begin{array}{l}\text { - Relocate gradually } \\
\text { the village }\end{array}$ & $\begin{array}{l}\text { - Construct } \\
\text { rockfills } \\
\text { - Build a } \\
\text { seawall }\end{array}$ \\
\hline Mirande Lagoon & $\begin{array}{l}\text { - Plant some } \\
\text { vegetation } \\
\text { - Renonce to the } \\
\text { access } \\
\text { - Do nothing }\end{array}$ & $\begin{array}{l}\text { - Relocate the road } \\
\text { and accept the } \\
\text { sea's progress } \\
\text { - Relocate the } \\
\text { campsite and } \\
\text { houses }\end{array}$ & $\begin{array}{l}\text { - Construct } \\
\text { rockfills }\end{array}$ \\
\hline $\begin{array}{l}\text { Isthmus of } \\
\text { Miquelon- } \\
\text { Langlade }\end{array}$ & $\begin{array}{l}\text { - Plant some } \\
\text { vegetation } \\
\text { - Set up a boat } \\
\text { connection } \\
\text { - Accept the } \\
\text { disappearance of } \\
\text { the isthmus }\end{array}$ & $\begin{array}{l}\text { - Enhance the road } \\
\text { - Relocate the road } \\
\text { - Build a bridge }\end{array}$ & $\begin{array}{l}\text { - Construct } \\
\text { rockfills }\end{array}$ \\
\hline
\end{tabular}

We summarized the average profile of the local population aged 18 and over and compared it with the total population of the archipelago. We used data from the last census fully available ${ }^{1}$ for Saint-Pierre-andMiquelon, conducted in 2014 by the French National Institute of Statistical and Economic Studies (INSEE), except for the income data, which comes from the annual report of the Financial Institute for Overseas Departments $^{2}$ (IEDOM). We did not seek to match every characteristic in our sample. The small differences in the sample between the two formats are summarized in Table 3 and presented below. To interpret the results of the whole sample, we carried out a statistical analysis, based on flat sorting and crossed tabulations. We use a Chisquare test of independence with a p-value $<0.05$ to assess the significance of the results.

\footnotetext{
1 The census tables are available here: https://www.insee.fr/fr/information/ 2409270.

${ }^{2}$ The last report is available here: https://www.iedom.fr/IMG/pdf/ra201 8_spm.pdf.
} 
Table 3

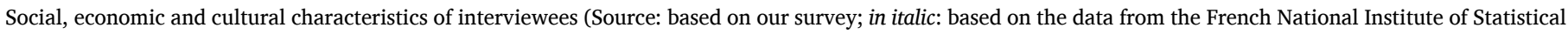
and Economic Studies (INSEE); with an asterisk *: based on the average data form the 2018 annual report of the Financial Institute for Overseas Department).

\begin{tabular}{|c|c|c|c|c|c|}
\hline & & TOTAL & $\begin{array}{l}\text { Face-to-face } \\
\text { Survey }\end{array}$ & $\begin{array}{l}\text { Online } \\
\text { Survey }\end{array}$ & $\begin{array}{l}\text { INSEE - Total population } \\
\text { (2014) }\end{array}$ \\
\hline \multirow[t]{2}{*}{ Gender } & Male & $50.5 \%$ & $45 \%$ & $56 \%$ & $50 \%$ \\
\hline & Female & $48.5 \%$ & $55 \%$ & $42 \%$ & $50 \%$ \\
\hline \multirow[t]{3}{*}{ Age } & $18-35$ & $30 \%$ & $30 \%$ & $29.5 \%$ & $23 \%$ \\
\hline & $36-55$ & $50.5 \%$ & $51 \%$ & $50 \%$ & $44 \%$ \\
\hline & $56-80$ & $19.5 \%$ & $19 \%$ & $18 \%$ & $33 \%$ \\
\hline \multirow[t]{3}{*}{ Location } & Saint-Pierre & $82.5 \%$ & $83 \%$ & $82 \%$ & $90 \%$ \\
\hline & Miquelon & $16 \%$ & $16 \%$ & $16 \%$ & $10 \%$ \\
\hline & Others place & $1 \%$ & $1 \%$ & $1 \%$ & $0,0 \%$ \\
\hline \multirow[t]{3}{*}{ Place of birth } & SPM & $66 \%$ & $63 \%$ & $68.5 \%$ & $97 \%$ \\
\hline & Mainland France & $28.5 \%$ & $30 \%$ & $27 \%$ & \\
\hline & Foreign country & $5 \%$ & $7 \%$ & $3 \%$ & $3 \%$ \\
\hline \multirow{3}{*}{$\begin{array}{l}\text { Permanently settled on } \\
\text { SPM }\end{array}$} & Less than 10 years & $17.5 \%$ & $20 \%$ & $15 \%$ & Unknown \\
\hline & More than 10 years & $19.5 \%$ & $24 \%$ & $15 \%$ & \\
\hline & Always lived in SPM & $62.5 \%$ & $56 \%$ & $69 \%$ & \\
\hline \multirow{3}{*}{ Property of their home } & Owner & $68.5 \%$ & $67 \%$ & $70 \%$ & $77 \%$ \\
\hline & Tenant & $21.5 \%$ & $23 \%$ & $20 \%$ & $19 \%$ \\
\hline & Free accommodation & $8.5 \%$ & $10 \%$ & $7 \%$ & $4 \%$ \\
\hline \multirow[t]{6}{*}{ Education level } & Primary and middle-high school & $5 \%$ & $4 \%$ & $6 \%$ & $34 \%$ \\
\hline & Pre-A-level diploma & $17 \%$ & $18 \%$ & $16 \%$ & $30 \%$ \\
\hline & A-level & $25.5 \%$ & $24 \%$ & $27 \%$ & $17 \%$ \\
\hline & Bachelor & $28.5 \%$ & $28 \%$ & $29 \%$ & $20 \%$ \\
\hline & Magister & $22.5 \%$ & $25 \%$ & $20 \%$ & \\
\hline & $\mathrm{PhD}$ & $0.7 \%$ & $0.7 \%$ & $0.7 \%$ & \\
\hline \multirow{7}{*}{$\begin{array}{l}\text { Socio-professional } \\
\text { category }\end{array}$} & Farmers & $0 \%$ & $0 \%$ & $0 \%$ & $0,2 \%$ \\
\hline & Artisans, merchants, company directors & $8 \%$ & $9 \%$ & $7 \%$ & $5 \%$ \\
\hline & Intellectual professions & $24 \%$ & $22 \%$ & $25.5 \%$ & $10 \%$ \\
\hline & Intermediary professions & $14.5 \%$ & $16 \%$ & $13 \%$ & $15 \%$ \\
\hline & Employees & $27 \%$ & $25 \%$ & $29.5 \%$ & $24 \%$ \\
\hline & Workmen & $8.5 \%$ & $13 \%$ & $4 \%$ & $14 \%$ \\
\hline & $\begin{array}{l}\text { Without activity (students, homemakers, pensioners, unemployed } \\
\text { people ...) }\end{array}$ & $12.5 \%$ & $15 \%$ & $10 \%$ & $33 \%$ \\
\hline \multirow[t]{3}{*}{ Annual income } & Less than $30000 €$ & $21.5 \%$ & $27 \%$ & $16 \%$ & $\sim 74 \% *$ \\
\hline & Between 31000 and $50000 €$ & $34 \%$ & $36 \%$ & $32 \%$ & $\sim 16 \% *$ \\
\hline & More than $51000 €$ & $30 \%$ & $24 \%$ & $36 \%$ & $\sim 10 \% *$ \\
\hline
\end{tabular}

The non-responses' rate is indicated in the Supplementary Material - Appendix B.

\section{Results}

\subsection{Characteristics of the people interviewed in the face-to-face and online survey}

Table 3 shows that our sample, combining face-to-face and online formats, is found to be representative for gender, place of residence and type of home, but it shows some differences with the profile of SaintPierre-and-Miquelon inhabitants in other aspects. People aged over 55 years old are less represented in our sample (20\%) than in the benchmark population (33\%), whereas persons aged 18-35 and 35-55 are over-represented (respectively $30 \%$ and $50 \%$ compared to $23 \%$ and $44 \%$ in the whole population). Intellectuals, graduates and better-off people are over-represented: more employees (27\% versus $24 \%$ in the whole population) and intellectual professions ( $24 \%$ versus $9 \%$ in the whole population) responded. We preferred to leave the sample as it was, unweighted, and to keep in mind the over-representation of more educated people when analysing the results. We consider that this does not affect our conclusions, as the sample nevertheless represents a significant proportion of the total population of the archipelago (5\%) and the other socio-professional categories remain present.

\subsection{Perceptions of climate change and its drivers}

Our sample is characterized by a high level of sensitivity to environmental issues, which rank second as a subject of concern for $64 \%$ of the interviewees, only coming after the local economic situation. Nearly all the participants (89\%) consider that Saint-Pierre-et-Miquelon is already affected by climate change [Table 4]. Changes in precipitation, temperature, winds, the coast, and biodiversity have been observed by more than $20 \%$ of the participants [Fig. 3]. In particular they describe local warming: a decrease in snow (68\%), and an increase in temperatures $(35 \%)$ that induce warmer winters $(60 \%)$ and warmer summers (26\%), along with the emergence of new land species (animal and plant) on the archipelago (24\%). Residents also perceive that windy conditions are becoming more frequent $(60 \%)$ and more severe $(44 \%)$. They also notice an increase in erosion of the coastline (44\%) and the disappearance of the coastal ice-foot (37\%). $61 \%$ of the participants are convinced that sea-level rise is already affecting the archipelago, and $24 \%$ said that they have actually observed this phenomenon [Table 4 and Fig. 3]. We also find a wider lack of knowledge or less clear perceptions when it comes to biodiversity and inland changes [Fig. 3]. Only $20 \%$ of the participants are convinced that climate change will have positive effects for the archipelago [Table 4]. Among them, 76\% mentioned the increase of air temperatures as a potential positive effect, $37 \%$ viewing this change as an opportunity for an extended tourist season and $24 \%$ thinking about agricultural opportunities [Table 4].

Most of the areas perceived as threatened by climate change are lowlying coastal areas. The isthmus of Miquelon-Langlade is considered as the most vulnerable place $(70 \%)$. Among the areas identified as vulnerable, three host human settlements [Table 4]: the village of Miquelon (68\%), the district of Les Graves (44\%) and the coastline of Saint Pierre town (23\%). The areas less emphasized are biodiversity or environmental hotspots, such as Mirande Lagoon (33\%) or Savoyard Lagoon (20\%). We investigated whether social and educational differences, the attachment of people to the territory or a different relationship to the environment have an impact on the responses [Appendix E]. The most significant results are linked to environmental awareness and to the level of place attachment. The more attached the person is to the territory, through ownership or a long time spent living in the 
Table 4

Perceptions of climate change and representations of adaptation in Saint-Pierreand-Miquelon.

\begin{tabular}{|c|c|c|c|}
\hline $\begin{array}{l}\text { Response } \\
\text { categories }\end{array}$ & Questions & Response & Percentage \\
\hline \multirow{22}{*}{$\begin{array}{l}\text { Climate change } \\
\text { representation }\end{array}$} & \multirow{3}{*}{$\begin{array}{l}\text { Existence of climate } \\
\text { change }(n=289)\end{array}$} & Yes & $89 \%$ \\
\hline & & No & $4 \%$ \\
\hline & & Don't Know & $7 \%$ \\
\hline & \multirow{4}{*}{$\begin{array}{l}\text { Eventuality of positive } \\
\text { effects to climate } \\
\text { change }(n=289)\end{array}$} & Yes & $20.5 \%$ \\
\hline & & No & $46 \%$ \\
\hline & & Maybe & $20 \%$ \\
\hline & & Don't know & $13.5 \%$ \\
\hline & \multirow{3}{*}{$\begin{array}{l}\text { Representations of the } \\
\text { positive effects of } \\
\text { climate change }(n=58)\end{array}$} & Increase in air & $76 \%$ \\
\hline & & temperatures & $37 \%$ \\
\hline & & $\begin{array}{l}\text { Extended touristic } \\
\text { season } \\
\text { Agricultural } \\
\text { opportunity }\end{array}$ & $24 \%$ \\
\hline & \multirow{12}{*}{$\begin{array}{l}\text { Preoccupation for } \\
\text { environment }(\mathrm{n}=289) \\
\text { Beliefs in sea-level rise } \\
\text { affecting Saint-Pierre- } \\
\text { and-Miquelon already } \\
(\mathrm{n}=289) \\
\text { Confidence in actors for } \\
\text { climate change } \\
\text { information's }(\mathrm{n}=140)\end{array}$} & Yes & $64 \%$ \\
\hline & & No & $36 \%$ \\
\hline & & Yes & $61 \%$ \\
\hline & & No & $14.5 \%$ \\
\hline & & Don't Know & $22.5 \%$ \\
\hline & & No answer & $2 \%$ \\
\hline & & Scientists & $58 \%$ \\
\hline & & Media & $33 \%$ \\
\hline & & Elders & $31 \%$ \\
\hline & & Itself & $29 \%$ \\
\hline & & Internet & $26 \%$ \\
\hline & & $\begin{array}{l}\text { Prefecture } \\
\text { (decentralized } \\
\text { State services) }\end{array}$ & $20 \%$ \\
\hline \multirow{13}{*}{$\begin{array}{l}\text { Sites perceived as } \\
\text { climate- } \\
\text { threatened }\end{array}$} & \multirow{4}{*}{$\begin{array}{l}\text { Island of Saint-Pierre } \\
(\mathrm{n}=289)\end{array}$} & District of Les & $44,5 \%$ \\
\hline & & Graves & $31.5 \%$ \\
\hline & & Île-aux-Marins & $23 \%$ \\
\hline & & $\begin{array}{l}\text { Coastline of the } \\
\text { town of Saint- } \\
\text { Pierre } \\
\text { Savoyard Lagoon }\end{array}$ & $20 \%$ \\
\hline & \multirow{9}{*}{$\begin{array}{l}\text { Island of Miquelon- } \\
\text { Langlade ( } \mathrm{n}=289)\end{array}$} & Isthmus of & $70.5 \%$ \\
\hline & & Miquelon-Langlade & $68 \%$ \\
\hline & & Miquelon Village & $33 \%$ \\
\hline & & Mirande Lagoon & $25.5 \%$ \\
\hline & & Grand Barachois & $22 \%$ \\
\hline & & Lagoon & $16.5 \%$ \\
\hline & & Grand Etang & \\
\hline & & Lagoon & \\
\hline & & The Petit Barachois & \\
\hline \multirow{22}{*}{$\begin{array}{l}\text { Representations of } \\
\text { adaptation }\end{array}$} & \multirow{3}{*}{$\begin{array}{l}\text { Beliefs in a successful } \\
\text { adaptation }(n=289)\end{array}$} & Yes & $86 \%$ \\
\hline & & No & $6 \%$ \\
\hline & & Don't know & $9 \%$ \\
\hline & \multirow{3}{*}{$\begin{array}{l}\text { Reasons of a successful } \\
\text { adaption }(n=120)\end{array}$} & Human always & $66 \%$ \\
\hline & & succeed to adapt/is & $29 \%$ \\
\hline & & $\begin{array}{l}\text { already adapting } \\
\text { Human will be } \\
\text { force to adapt } \\
\text { Human will adapt } \\
\text { until a certain } \\
\text { point }\end{array}$ & $5 \%$ \\
\hline & \multirow{2}{*}{$\begin{array}{l}\text { Reasons of adaptation's } \\
\text { failure }(\mathrm{n}=12)\end{array}$} & Nobody want to & $58 \%$ \\
\hline & & $\begin{array}{l}\text { change/have the } \\
\text { money to change } \\
\text { It is too late }\end{array}$ & $42 \%$ \\
\hline & \multirow{8}{*}{$\begin{array}{l}\text { Time scale for } \\
\text { archipelago's } \\
\text { adaptation }(n=289 \text { ) }\end{array}$} & Now & $52 \%$ \\
\hline & & Within 10 years & $31 \%$ \\
\hline & & Within 30 years & $9 \%$ \\
\hline & & Within 80 years & $1 \%$ \\
\hline & & Already adapted & $1 \%$ \\
\hline & & Impossible & $1 \%$ \\
\hline & & Don't know & $4 \%$ \\
\hline & & No-answer & $1 \%$ \\
\hline & \multirow{6}{*}{$\begin{array}{l}\text { Actors of adaptation ( } \mathrm{n} \\
=289 \text { ) }\end{array}$} & Territorial & $60 \%$ \\
\hline & & Community (Local & $50 \%$ \\
\hline & & Services) & $48 \%$ \\
\hline & & Everybody & $45 \%$ \\
\hline & & Prefecture (State & $44 \%$ \\
\hline & & Services) & $33 \%$ \\
\hline
\end{tabular}

Table 4 (continued)

\begin{tabular}{|c|c|c|c|}
\hline $\begin{array}{l}\text { Response } \\
\text { categories }\end{array}$ & Questions & Response & Percentage \\
\hline & \multirow{15}{*}{$\begin{array}{l}\text { Willingness to pay a tax } \\
(\mathrm{n}=289)\end{array}$} & Municipality & $31 \%$ \\
\hline & & French & $25 \%$ \\
\hline & & Government & $21 \%$ \\
\hline & & Itself & \\
\hline & & Overseas & \\
\hline & & Territories & \\
\hline & & Ministry & \\
\hline & & Other inhabitants & \\
\hline & & Firms & \\
\hline & & Yes & $28 \%$ \\
\hline & & Yes under certain & $44 \%$ \\
\hline & & conditions & $24 \%$ \\
\hline & & No & $2 \%$ \\
\hline & & Don't know & $2 \%$ \\
\hline & & No-answer & \\
\hline
\end{tabular}

archipelago, the more likely they are to have observed climate-related phenomena. Moreover, those who show environmental awareness are more likely to highlight local manifestations of climate change.

\subsection{Social perceptions of adaptation solutions}

Nearly all the participants consider that human adaptation in SaintPierre-and-Miquelon will be successful (86\%) [Table 4]. Among those, $66 \%$ consider that humanity as a whole has the capacity to plan and implement adaptation, whereas $29 \%$ state that only reactive adaptation will prevail, and $5 \%$ estimate that adaptation will be successful up to a certain point [Table 4]. We studied the inhabitants' perceptions of seven adaptation measures at the archipelago scale. Six of them are accepted by more than $50 \%$ of participants [Fig. 4]. Nature-based solutions are the most widely accepted measures (87\%), followed by limiting the construction of buildings (74\%) and participation in coastal monitoring (73\%). Crisis drills (64\%) and the creation of a local adaptation aid fund (63\%) are also rather well accepted. The two last measures - adapting houses and new, restrictive local regulations for adaptation - would be more constraining for daily life and we found that they appear to be less acceptable for respondents.

The drivers of perceptions differ greatly for each measure [Appendix E]. Socio-demographic variables are significant for some measures, like the level of education: people with a higher diploma are more likely to accept limitations on construction of new buildings. Variables linked to the level of place attachment are also statistically significant. The more people are attached to the territory, the less ready they are to accept restrictive measures. However, perceptions of the solutions also vary greatly, depending on each local context [Fig. 5]. We found that soft solutions, such as planting or even abandoning a site, are better accepted when it comes to leisure areas: the Miquelon-Langlade isthmus, the Îleaux-Marins and Savoyard Lagoon. On the contrary, hard solutions are preferred for places with greater issues: the coastline of the town of Saint Pierre or the airport, both places that are either an economic hub, residential centre or critical infrastructure for keeping the territory open and for health and security. Respondents only chose intermediate solutions - mainly relocation - for two places where the issues are different: Miquelon village (89\%) and the road to Mirande Lagoon $(50 \%)$. For some places, such as the Saint Pierre coastline, Miquelon Village, Mirande Lagoon and the airport, we observed disagreements between supporters of hard solutions and those in favour of intermediate solutions. On average, the acceptance of adaptation measures is good, but depends on the kind of solution and on each local context.

\subsection{Social perceptions of adaptation planning and implementation}

Nearly all the participants express a sense of urgency as regards adaptation to climate change in Saint-Pierre-and-Miquelon: $92 \%$ wish to 


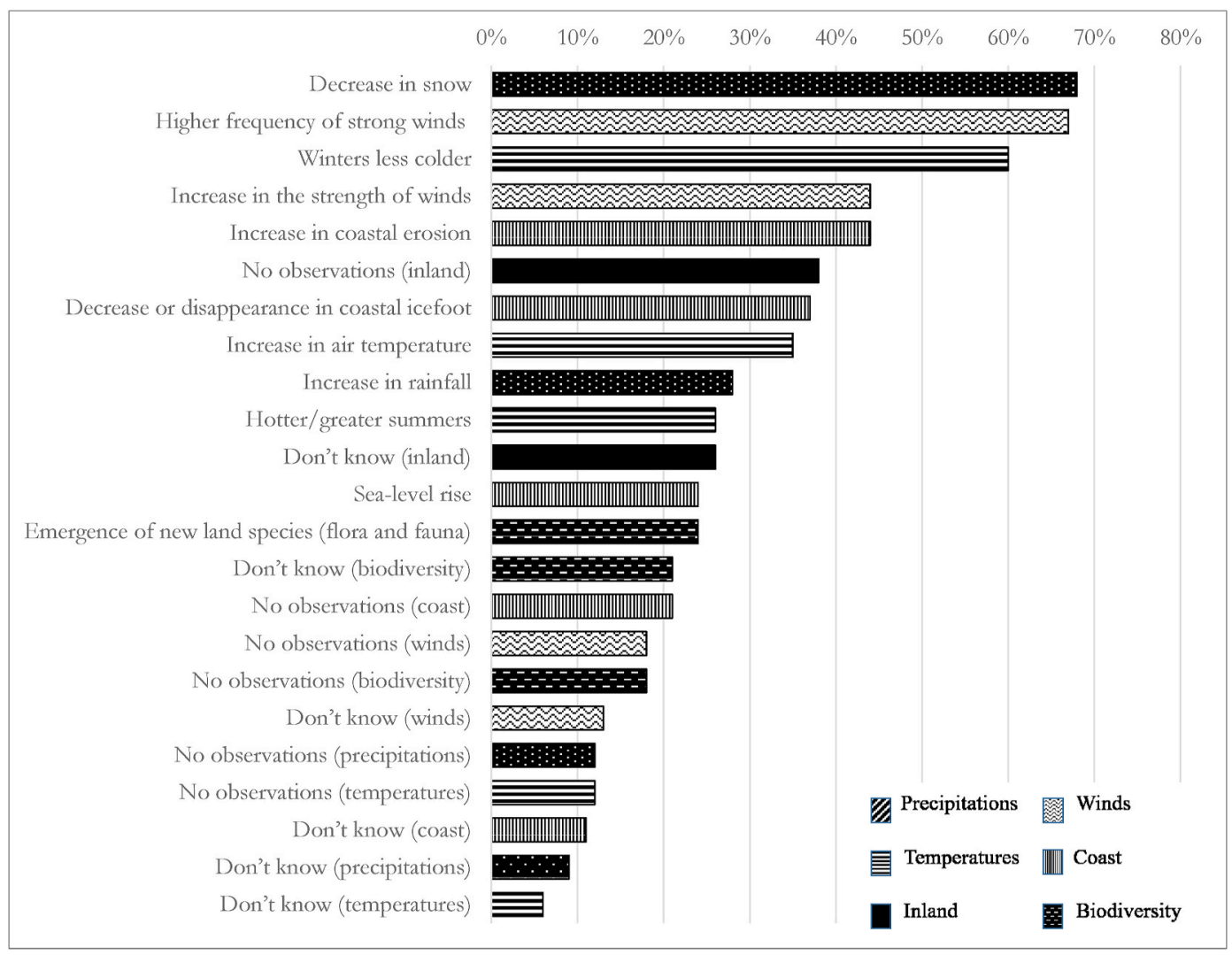

Fig. 3. Perceptions of local effects of climate change on environment. Sample: 289 persons.

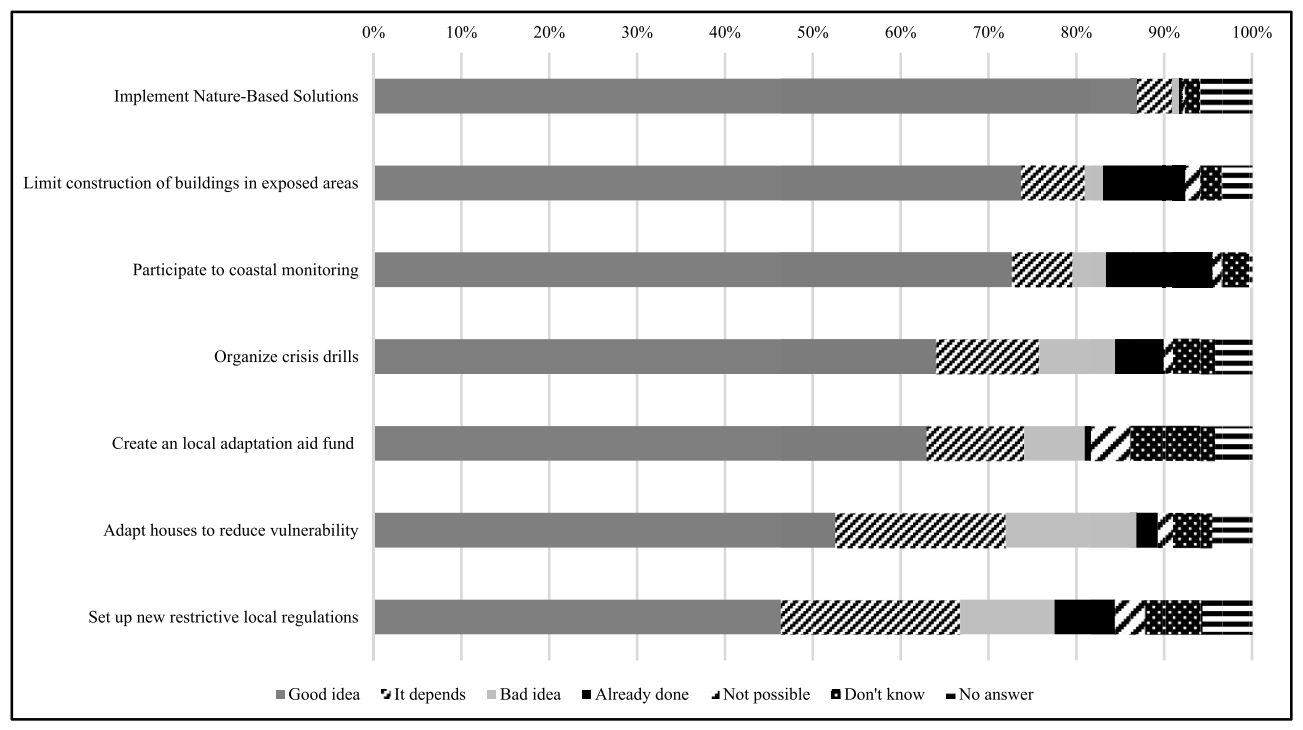

Fig. 4. Acceptance of adaptations' measures at archipelago scale in Saint-Pierre-and-Miquelon. Sample: 289 persons.

see early adaptation in the archipelago, within the next 30 years, and more than half even wish to see immediate adaptation [Table 4]. This demand for early implementation is expressed for all the adaptation measures we studied, at both the local and the archipelago scales, even if the time frame varies depending on the kind of measure [Figs. 6 and 7]. Very few interviewees seem to consider the 80 -year time scale as relevant. At the archipelago scale, the most acceptable solutions (naturebased solutions, building limitations, coastal monitoring) are seen as the most urgent to implement [Fig. 6]. At the local scale, the choice of time scale seems to be independent of the place's issues and instead linked to the kind of solution [Fig. 7]. Interviewees choose the closest time scale for hard solutions, whereas they allow more time, sometimes 80 years, for soft solutions and relocation. However, respondents seem to give higher priority to a rapid implementation of adaptation for four places: the Saint-Pierre coastline, Miquelon Village, the Île-aux-Marins and the Savoyard Lagoon. Broadly, we observe a local sense of urgency for adapting to climate change.

Interviewees were invited to choose several kinds of actor - such as the national or local authorities, companies, associations, relatives, the neighbourhood, etc. - likely to provide the most reliable information on 


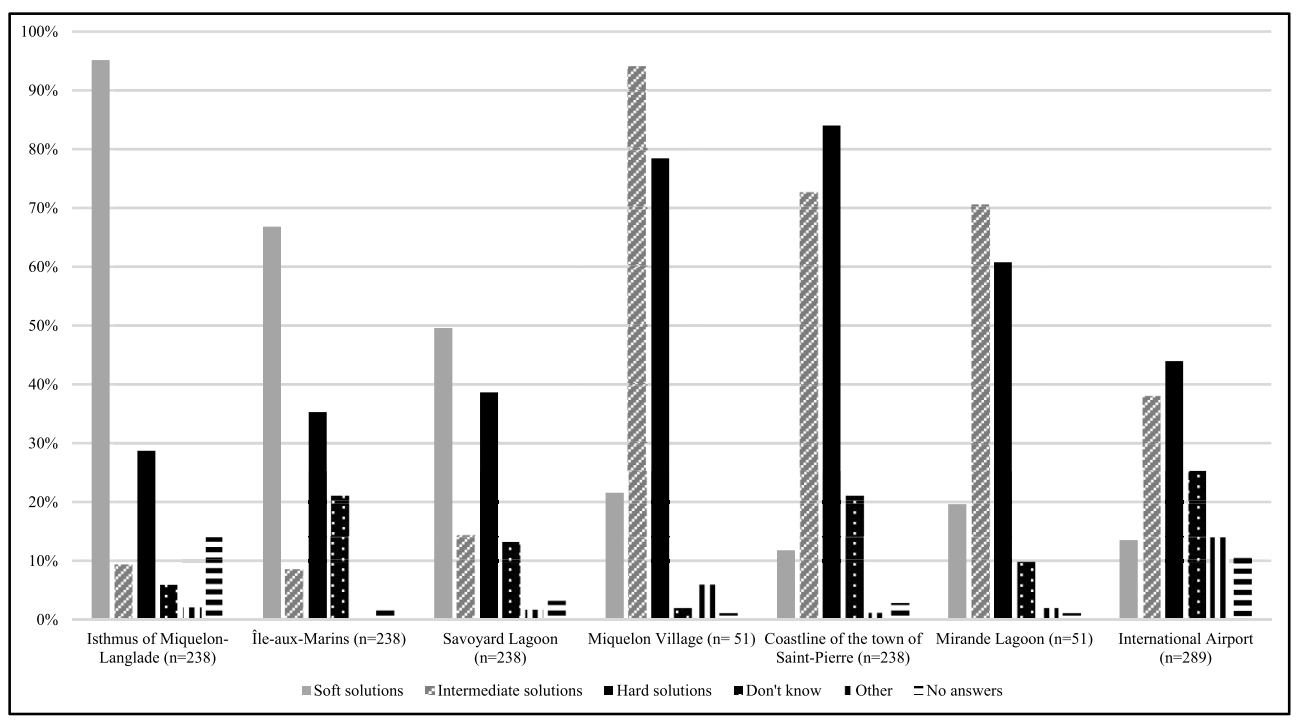

Fig. 5. Acceptance of adaptation's measures depending of the place. Sample: 289 persons.

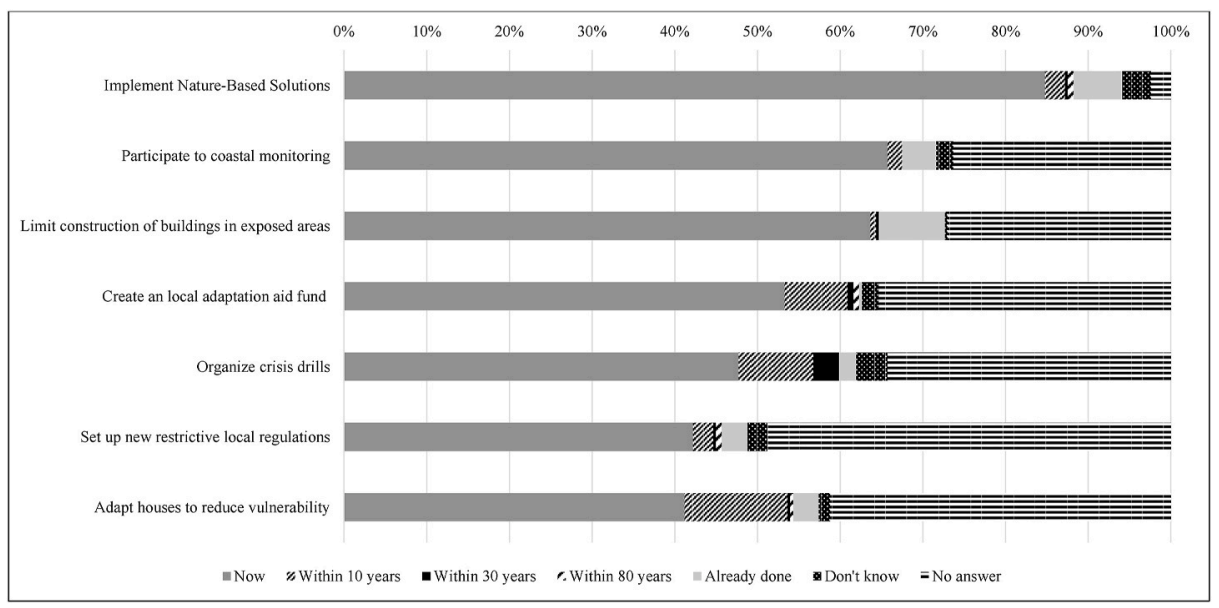

Fig. 6. Choice of a time scale for each adaptation's measures at the archipelago's scale. Sample: 289 persons.

climate change: they consider scientists as the most legitimate actors (58\%) [Table 4]. However, trust in science depends on the level of education: the more educated people are, the more likely they are to trust scientists [Appendix E]. Following the scientists, we find the media (33\%), the Elders (31\%) - old people considered as keepers of the local customs and the past, - Internet (26\%) and themselves (29\%) [Table 4]. The Prefecture, which hosts decentralized state services, is the only public actor who appears as trustworthy and only for $20 \%$ of the respondents, which is very low. The participants also selected various actors to implement adaptation measures [Table 4]. The Territorial Community, the local and semi-independent governing body, is seen as the main actor for adaptation (60\%), but all the public services existing in Saint-Pierre-and-Miquelon are widely mentioned by the interviewees: state local services (48\%), municipalities (45\%) and government (44\%). Although participants seem to be cautious about the information these actors deliver, they consider them as the most legitimate when it comes to adaptation. Beside the public authorities, the participants also consider citizens as key-actors (50\%). Private companies are considered as an actor for local adaptation by a minority of our sample (21\%), wich can be explained by the economic structure of the archipelago: public services are the main economic actors, while the number and size of private companies remain small. As for themselves personally, interviewees consider that they are not the most relevant actors for implementing adaptation measures (33\%). However, they seem to be partly ready to participate financially [Table 4] through a local tax (24\% said "yes" and 44\% "yes under certain conditions").

\subsection{Differences in responses depending on the survey's format}

While the use of online and face-to-face formats revealed some small differences in the answers [Fig. 8], the results of both formats are similar and consistent. The online interviewees seem to be more preoccupied by the environment than the others and more pessimistic about the eventual positive effects of climate change for the archipelago. Online respondents and face-to face interviewees seem to have different concerns about the locally observed changes, as illustrated in Fig. 8. Online interviewees demand slightly faster implementation of adaptation measures (now $=60 \%$ versus $40 \%$; in 10 years $=26 \%$ versus $36 \%$ ), but at the same time, seem less willing to accept adaptation solutions. Finally, we found that online interviewees expect a stronger individual investment from everybody, whereas face-to-face participants expect more from public services. 


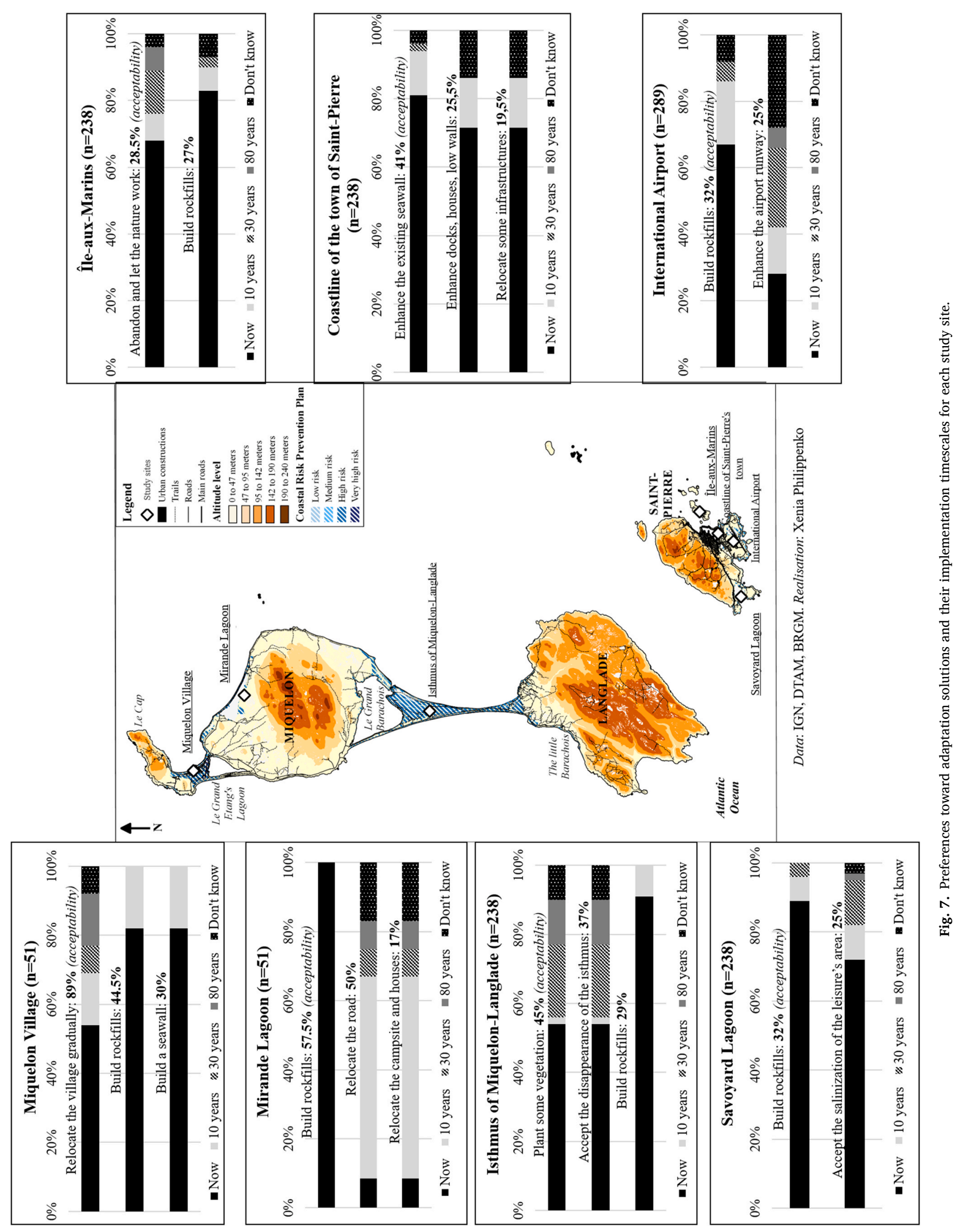




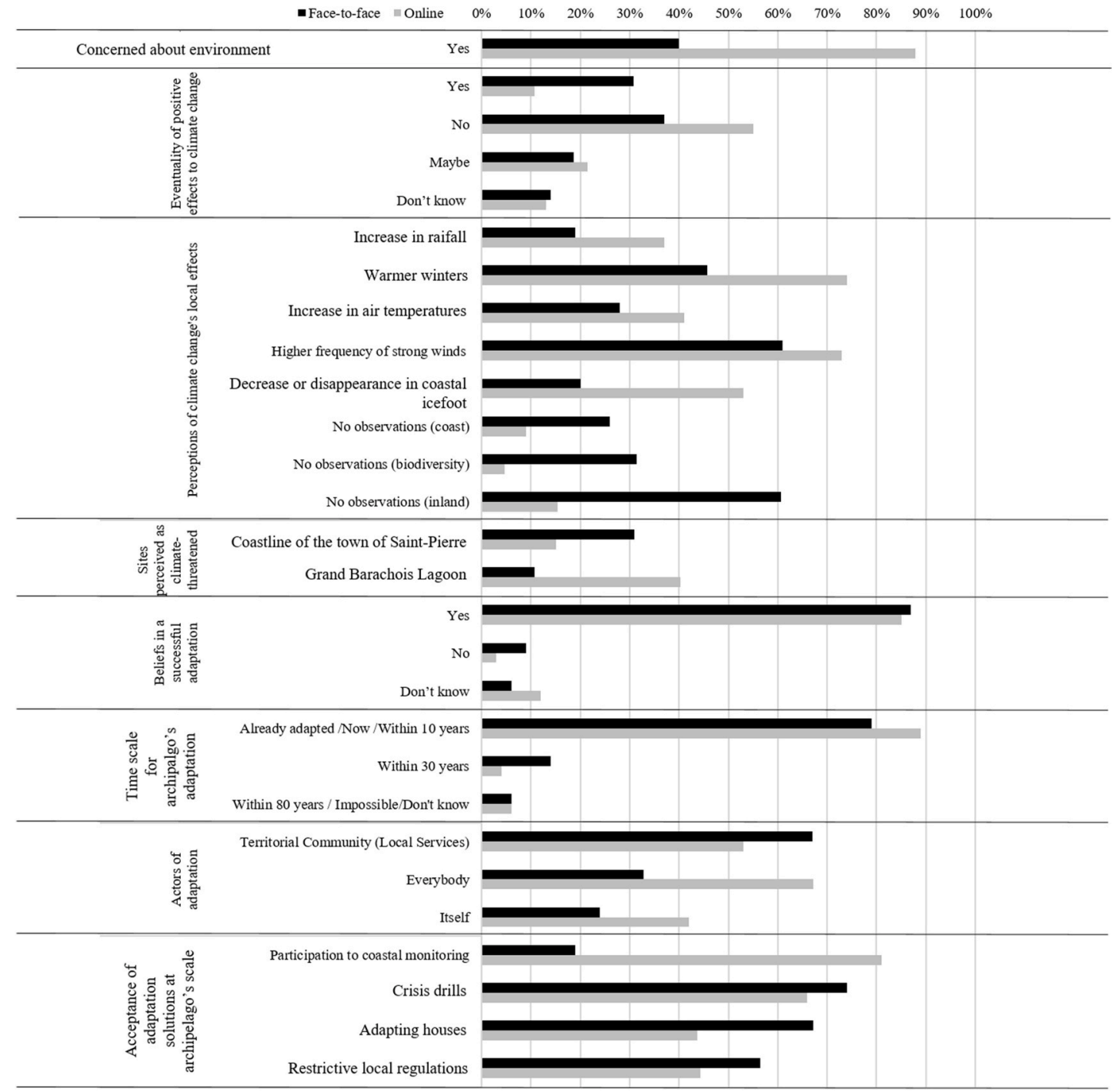

Fig. 8. Differences of answer depending on the survey's format (confirmed by results of the $\chi^{2}$-test with a p-value $<0.05$ ). Sample: 140 face-to-face, 149 online.

\section{Discussion}

\subsection{Climate change perceptions depend on environmental awareness and knowledge of the territory}

Very few people seem sceptical about climate change in Saint-Pierreand-Miquelon. The fact that some of the effects are already observable may influence this result, as suggested by the responses referring to the most easily observable phenomena such as erosion, decrease in snow and warmer temperatures. The comparison between the scientific literature and inhabitants' perceptions shows some consistency. No long-term datas is available for the archipelago of Saint-Pierre-andMiquelon, but the Canadian data and IPCC reports (Romero-Lankao et al., 2014; Lemmen et al., 2016; Bush et Lemmen et al., 2016) indicate some trends [section 2]. The increasing air temperatures, the decrease in snow and the coastal erosion are well identified by the residents, in agreement with scientific data. These perceptions are quite similar to those observed by Friesinger and Bernatchez in several places in Atlantic Canada (2010). Regarding the changes in wind regime, the perceptions of Saint-Pierre-and-Miquelon residents are quite similar to those observed in Atlantic Canada (Friesinger et Bernatchez, 2010; Vasseur et al., 2017) and to what some recent research suggests (Ford et al., 2017), even if current scientific knowledge cannot yet confirm the potential influence of climate change on this. Surprisingly, the residents of
Saint-Pierre-and-Miquelon do not identify the decrease of the coastal ice-foot as a consequence of climate change. Other expected effects, such as the seasonal decrease in peatland frost, the increase in rainfall or observations regarding biodiversity or changes inland, are mentioned less or not at all.

Some environmental and cultural factors may explain this: 1) these effects are difficult to measure and can only be detected with recurrent and regular observations and advanced knowledge; 2) insularity may favour observations in coastal areas; 3 ) these effects are less highlighted in media coverage, at the local and international level. The role of media in the construction of perceptions is well known (Osberghaus et al., 2010; Weber, 2016). Nevertheless, the inhabitants identified many biodiversity hotspots as the most vulnerable to climate change, such as the Grand Barachois or Savoyard Lagoon. This shows that people are aware of changes linked to climate change that affect biodiversity. Moreover, the coastal places identified as threatened by the climate are mostly consistent with those identified in the regulatory Coastal Risk Prevention Plan [see Section 2], which indicates clear perception of the most vulnerable local areas, even though their boundaries are not very accurate.

Our results therefore highlight relatively good local knowledge of the effects of climate change, contrary to some other studies, which identified a gap between experts' and residents' perceptions (Lata and Nunn, 2012; Coquet et al., 2018). The fact that very few tourists or seasonal 
residents live in the archipelago may partly explain those clear perceptions. Nevertheless, the presence of some people from the mainland France, who are mostly newcomers, points to a difference in knowledge between populations. People who are native to Saint-Pierre-and-Miquelon and those attached to the territory (owners and/or residents for 10 years) demonstrate greater knowledge about climate change, regardless of their level of education. This confirms the importance of local knowledge and of place attachment, as underlined by previous studies (Minéo-Kleiner, 2017; Goeldner-Gianella et al., 2019). As is well known, perceptions are also linked to experience of natural coastal hazards: the identification of climate-threatened places is better among those having experienced these hazards (Lawrence et al., 2014). This can be observed especially among Miquelon residents: their awareness seems to be stronger - probably because they suffered damage after a storm in November 2018, a few months before our questionnaire.

Finally, in Saint-Pierre-and-Miquelon we observed that environmental awareness and perceptions of climate change are linked, as reported in other studies (O'Connor et al., 1999; Lammel et al., 2013). We can see for example that people concerned with environmental issues are more likely to attribute observed changes to climate change than those who do not consider the environment as a concern [Appendix E]. However, it is difficult to conclude which of awareness and perceptions is the driver of the other (Weber, 2016). We may suppose that people with strong environmental awareness are more likely to pay closer attention to climate change impacts (Shao and Goidel, 2016) or that people who observed changes in their territory could be more likely to be convinced of and concerned about climate change (Taylor et al., 2014).

\subsection{Social acceptance of adaptation depends on place attachment, experience of natural hazards and socio-demographic characteristics}

The population of our sample is very optimistic about the archipelago's successful adaptation; very few consider the option of the human population disappearing. This optimism comes from a strong confidence in human capacity and technology, which is typically an "evolutionary attitude" (Lammel et al., 2013). If we look at the social acceptance of adaptation solutions, the population seems to accept the need to change and adapt to climate change. In contrast with the observations made by Friesinger and Bernatchez (2010) in several places in Atlantic Canada except in Sept-Îles - soft solutions are well accepted, both in general and at the local scale for each of the seven places we studied. A possible partial explanation is that planting dune vegetation has already been done since the $2010 \mathrm{~s}^{\prime}$ on the isthmus of Miquelon-Langlade, and has partly preserved the beaches. Another explanation may come from the population's better understanding of coastal dynamics and defences over the last ten years, as observed in some other French localities (Rey-Valette et al., 2019). This might also have improved the acceptance of measures that are usually unpopular, such as the limitation on construction or relocation. Local personalities may also have played a role in local awareness and the rather high acceptance (Agrawal, 2008; Measham et al., 2011): some are considered as "local experts" in the fields of environment and biodiversity, and others are local elected officials, past or present, leaders on the issues of coastal risks, climate change and adaptation. However, we observed that the interviewees are less willing to accept restrictive measures and seem distrustful of measures from the public authorities. This might come from the observed lack of confidence in public authority in general and in the information that they deliver on climate change: the link between social acceptance and the level of confidence in actors has already been highlighted in the literature (Cash et al., 2003; Raufflet, 2014; Fournis and Fortin, 2015; Jones and Clark, 2014; Rey-Valette et al., 2019).

Nonetheless, the social acceptance of the different types of solutions is also linked to the inhabitants' profile or personal history. First, personal experience of coastal hazards has an impact on the acceptability process. It may cause a shock or sudden awareness: the person then is more interested in one particular solution than in the others (Lawrence et al., 2014; Thistlethwaite et al., 2018). Secondly, the place of residence - near the sea or not - may influence the way the risk is perceived as theoretical or real, and therefore affect the degree of acceptance of adaptation measures (O'Neill et al., 2016; Coquet et al., 2018). Thirdly, cultural capital plays a role in acceptance: the better-educated people are and the better their professional position, the more they may accept intermediate or soft solutions, taxes and restrictive regulations [Appendix E]. This might come from a better understanding of how climate change operates and what the impacts of the different solutions are (Muttarak and Lutz, 2014). It highlights the importance of providing specific education on climate change and natural hazards in the early years of school (Lee et al., 2015; Borde et al., 2020) and which should be specific to each local context in French overseas areas (Oiry and Grancher, 2019).

Finally, the level of place attachment plays a major role in the acceptability of adaptation solutions, either improving acceptance or lowering it (Devine- Wright, 2009; Amundsen, 2015). We saw that people attached to the territory have clearer perceptions of the effects of climate change: we might have thought that it would improve their acceptance of adaptation solutions. But on the contrary, they seem reluctant to change and to accept constraints, in contrast with incomers from the mainland, who seem to be more proactive: place attachment is then a barrier to adaptation. Several elements may explain why people from the mainland are more open to change and would accept some constraints. First, they often are better educated and therefore more likely to accept and understand the merits and constraints of a solution. Secondly, they only live in the archipelago for a few years: they are not concerned in the long term or are less attached to the territory (Agyeman et al., 2009; Costas et al., 2015). In addition, they are more worried because of their unfamiliarity with natural hazards. Finally, they do not perceive the financial cost of adaptation and the constraints in the same way as the natives, probably considering these more theoretically, whereas natives may be more cautious and anxious. Therefore, incomers from the mainland are more likely to ask for action and to be ready to engage in it themselves, whereas local people are more likely to view public authorities as the main protagonists (Minéo-Kleiner, 2017; Thistlethwaite et al., 2018).

The village of Miquelon, mostly inhabited by native people, is the exception: residents are especially proactive and accept, or even demand, a relocation of the village. Usually, both the population and the various actors involved are reluctant to relocate: the reasons can be institutional or political (Abel et al., 2011; Gibbs, 2016), financial (Creach et al., 2020), judicial (Lambert, 2015), or personal (King et al., 2014; Costas et al., 2015). However, relocation may be better accepted in arctic or subarctic places facing strong threats from climate change (Bronen and Chapin, 2013; Amundsen, 2015). At Miquelon, the high social acceptance of relocation may be a consequence of four factors. First, the implementation of a Coastal Risk Prevention Plan and its rules on the limitation of construction alerted the population, sometimes generating tensions, as underlined in certain documents from public actors. ${ }^{3}$ Secondly, the authorities have made multiple efforts to explain and convince the population of the necessity to relocate. ${ }^{4}$ Thirdly, the storms in November 2018, which caused coastal flooding in the village and made the impacts of sea-level rise and climate change impacts more tangible (Alexander et al., 2012), seemed to have a strong impact on householders' minds, as Abel et al. (2011) and King et al. (2014)

\footnotetext{
${ }^{3}$ Some of these documents can be found in French here: https://www.jo-spm. fr/doc_jo/DELIB2015-0245.pdf or here: http://www.archipeldemain.com/le pineuse-question-du-pprl/.

4 As suggested by this newspaper article in French: https://la1ere.francetvin fo.fr/saintpierremiquelon/miquelon-langlade/montee-eaux-nouvelle-reunion -publique-pprl-miquelon-782261.html.
} 
observed in other places. Finally, the strong place attachment of inhabitants leads to a proactive attitude in order to find solutions to stay on the territory and make it an opportunity for development. The place attachment then becomes an opportunity for adaptation (Amundsen, 2015).

The high acceptance of relocation is even more surprising when we consider the desired time scale for implementation, which is within the next three decades. In general, studies have shown that relocation might be accepted, but usually with longer time scales (Minéo-Kleiner, 2017; Rey-Valette et al., 2019). This sense of urgency for implementing adaptation solutions in Miquelon, and in Saint-Pierre-and-Miquelon more generally, is uncommon: other studies highlight that the economic situation, pollution or waste problems are more likely to be seen as urgent issues, especially in island communities (Terorotua et al., 2020). In Saint-Pierre-and-Miquelon, this sense of urgency for adaptation may indicate both a sudden awareness of the risks and a wish to preserve the territory, due to strong place attachment. This may be confirmed by the fact that the online participants, who were more likely to state an environmental concern and to be natives and therefore attached to the territory, appear to be more anxious. In all events, this general sense of urgency is a significant message for the public authorities: even if the social acceptance of the solutions is not always unanimous, the population calls for action and management of adaptation. The fact that the residents choose different time scales for some solutions or some places with important issues is interesting. It may indicate the need for a dynamic plan taking into account the complexity of the situation and the design of local adaptation pathways (Haasnoot et al., 2019; Rocle et al., 2020). Our results confirm the necessity to use this kind of management tool to anticipate successful adaptation (Stephens et al., 2018) and the importance of integrating social perceptions within these plans (Bronen and Chapin, 2013).

\subsection{Interest in an online format for isolated but connected territories}

The simultaneous use of two different survey formats allowed us to highlight aspects that could be useful for future socio-environmental research using web surveys and looking for information about the pertinence of this format and its influence on the answers [as detailed in Appendix A to D]. Online respondents are more likely have environmental concern that impact on their answers. Indeed, online interviewees are more pessimistic about the climate change effects and ask for a faster implementation of adaptation measures. The presence or absence of the interviewer may also have influenced answers: for the face-to-face questionnaire, the residents may feel a pressure from the interviewer, thus delivering the answers they perceived as "expected"; conversely, the online interviewees may have felt freer to answer what they really thought (Frippiat and Marquis, 2010). In a web-based survey it is important to understand the influence of the design on answers. We find out that open-ended questions did not work very well online: the non-response rate is the highest of our study. On the contrary, when we substitute the spontaneous answer with a list of items, as we did online for the choice of local effects of climate change, the online responses are higher [Fig. 7; Appendix A and B].

We observed that more people answering online were native [Table 3], suggesting that a web-survey may be well accepted in some small islands communities and isolated territories, mostly inhabited by native people. Côté (1999) and Cave (2012) showed the growing importance of Internet in peripheral and isolated territories. We noted the importance of social media and Internet in Saint-Pierre-and-Miquelon, which is why we opted for a web survey. Facebook is very popular, and the archipelago inhabitants have their own website (Cheznoo.com), relaying all kinds of information, including a link to our survey. The lack of any other media, apart from the local TV-, radio- and web-channel SPM la lère, has been conducive to the population's digitalization. We therefore conclude that web surveys can be an appropriate tool for geographically isolated but well-connected territories: used as a complement to other survey formats, they can help to collect data in territories that are often difficult to access. The format has, however, its own limits [Appendix C and D] and is more likely to reach a specific sample of people already aware or engaged in environmental causes. The results must therefore be used with care by public authorities in developing adaptation strategies.

\section{Conclusion}

For this paper, we performed a social survey in Saint-Pierre-andMiquelon, a subarctic island located in the Gulf of St Lawrence. Perceptions of the local effects of climate change are broadly consistent with the current scientific knowledge, even if not entirely accurate. This shows good awareness of climate change and its impacts. However, perceptions appear to depend on the profile of individuals and to be linked with their environmental awareness and level of place attachment [Section 5.1]. Adaptation solutions are well accepted in general, and even the principle of relocation seems to be accepted, or at least understood, which contrasts with many other places where social acceptance of relocation is lower, such as in mainland France, Canada or other small French overseas islands. We found that perceptions of adaptation vary somewhat depending on the kind of solution, the places' specific issues and the profile of respondents. In fact, experience of past disasters improves social acceptance of adaptation measures, whereas people attached to their territory are less ready to accept constraining solutions, such as new regulations [Section 5.2]. A sudden rise in the awareness of climate change and coastal hazards may explain the strong sense of urgency about implementing local adaptation solutions. Finally, we show that the level of trust in various actors may explain differences in acceptance of some adaptation solutions. This conclusion is particularly relevant for public actors currently supporting the adaptation process in Saint-Pierre-and-Miquelon and presumably elsewhere. Hence, a dynamic plan that provide the opportunity to adapt to the changing reality may be a useful management tool. Finally, our study provides methodological insights for future social surveys regarding adaptation: we highlight the interest of using both online and face-toface surveys simultaneously in a geographically isolated but wellconnected archipelago, although the format has its limits [Section 5.3].

This situation may rapidly evolve and local perceptions of adaptation may change. On one hand, the current pandemic context may increase concern in health and economic issues, to the detriment of environmental questions. On the other hand, increasing environmental awareness around the world and increased migrations, including young people moving to mainland France and Canada for study or work, may provide opportunities for climate change adaptation. Moreover, the rapid changes experienced in subarctic areas may increase the sense of urgency, provide for faster mobilization than in temperate climate areas, and contribute to a rapid evolution of local perceptions, in either direction, as suggested by the episodes of significant erosion on the isthmus of Miquelon-Langlade in February and March 2, $021 .^{5}$

\section{Contributors}

XP: performed the research, conceived the survey, performed the survey in the field, performed statistical analysis and wrote the manuscript. LGG: designed the research, conceived the survey and performed the survey in the field. DG: conceived the survey and contributed to the statistical analysis. GLC: designed the research, contributed to the

\footnotetext{
${ }^{5}$ As suggested in these newspaper articles in French: https://la1ere.france tvinfo.fr/saintpierremiquelon/miquelon-langlade/1-erosion-de-1-isthme-demiquelon-langlade-au-c-ur-des-preoccupations-936697.html and https://la1ere .francetvinfo.fr/saintpierremiquelon/miquelon-langlade/isthme-dunaire-de-mi quelon-langlade-fragilisee-par-la-mer-la-route-reliant-miquelon-a-langlade-acede-944302.html.
} 
analysis. YDLT: leader of the program, designed the research. All authors contributed to writing and correcting the manuscript. All read and approved the final manuscript.

\section{Financial support}

This work was supported by grants from the French National Geological Survey (BRGM) and the French Government.

\section{Declaration of competing interest}

The authors declare the following financial interests/personal relationships which may be considered as potential competing interests

\section{Acknowledgements}

The authors thank the three anonymous reviewers for their constructive comments, which helped to improve this manuscript. We are grateful for advice or support from the local organizations: the DTAM and especially Jean-Michel SCHMITT; the Collectivité Territoriale, especially Vicky CORMIER, the staff of the Maison de la Nature and of the Pôle Développement Durable; the two municipalities; the local media SPM la 1ère. We thanks all the anonymous respondents to the survey, the people who tested, corrected and gave advices for the survey, and Jean CRNOKRAK who developed a Python code to optimize the analysis of the results. We thank Andrew MORRIS for correcting this manuscript.

\section{Appendix A. Supplementary data}

Supplementary data to this article can be found online at https://doi. org/10.1016/j.ocecoaman.2021.105924.

\section{References}

Abel, N., Gorddard, R., Harman, B., Leitch, A., Langridge, J., Ryan, A., Heyenga, S., 2011 Sea level rise, coastal development and planned retreat: analytical framework, governance principles and an Australian case study. Environ. Sci. Pol. 14, 279-288. https://doi.org/10.1016/j.envsci.2010.12.002.

Adger, W.N., Dessai, S., Goulden, M., Hulme, M., Lorenzoni, I., Nelson, D.R., Naess, L.O., Wolf, J., Wreford, A., 2009. Are there social limits to adaptation to climate change? Climatic Change 93, 335-354. https://doi.org/10.1007/s10584-008-9520-z.

Agrawal, A., 2008. In: The Role of Local Institutions in Adaptation to Climate Change. Papers of the Social Dimensions of Climate Change Workshop. The World Bank. https://doi.org/10.1596/28274.

Agyeman, J., Devine-Wright, P., Prange, J., 2009. Close to the edge, down by the river? Joining up managed retreat and place attachment in a climate changed world. Environ. Plann.: Econ. Space 41, 509-513. https://doi.org/10.1068/a41301.

Alexander, K.S., Ryan, A., Measham, T.G., 2012. Managed retreat of coastal communities: understanding responses to projected sea level rise. J. Environ. Plann. Manag. 55, 409-433. https://doi.org/10.1080/09640568.2011.604193.

Amundsen, H., 2015. Place attachment as a driver of adaptation in coastal communities in Northern Norway. Local Environ. 20, 257-276. https://doi.org/10.1080/ 13549839.2013.838751.

Biesbroek, G.R., Swart, R.J., Carter, T.R., Cowan, C., Henrichs, T., Mela, H., Morecroft, M.D., Rey, D., 2010. Europe adapts to climate change: comparing national adaptation strategies. Global Environ. Change 20, 440-450. https://doi. org/10.1016/j.gloenvcha.2010.03.005.

Billy, J., Robin, N., Hein, C.J., Certain, R., FitzGerald, D.M., 2015. Insight into the late Holocene sea-level changes in the NW Atlantic from a paraglacial beach-ridge plain south of Newfoundland. Geomorphology 248, 134-146. https://doi.org/10.1016/j. geomorph.2015.07.033.

Borde, B., Léna, P., Lescarmontier, L., 2020. Education as a strategy for climate change mitigation and adaptation. In: Lackner, M., Sajjadi, B., Chen, W.-Y. (Eds.), Handbook of Climate Change Mitigation and Adaptation. Springer, New York, NY, pp. 1-25. https://doi.org/10.1007/978-1-4614-6431-0_149-1.

Brinkman, T.J., Hansen, W.D., Chapin, F.S., Kofinas, G., Burn-Silver, S., Rupp, T.S., 2016. Arctic communities perceive climate impacts on access as a critical challenge to availability of subsistence resources. Climatic Change 139, 413-427. https://doi. org/10.1007/s10584-016-1819-6.

Bronen, R., Chapin, F.S., 2013. Adaptive governance and institutional strategies for climate-induced community relocations in Alaska. Proc. Natl. Acad. Sci. Unit. States Am. 110, 9320-9325. https://doi.org/10.1073/pnas.1210508110.

Bush, E., Lemmen, D.S., 2019. Canada's Changing Climate Report, Environment and Climate Change Canada. Government of Canada, Ottawa, p. 444.
Canosa, I.V., Ford, J.D., McDowell, G., Jones, J., Pearce, T., 2020. Progress in climate change adaptation in the Arctic. Environ. Res. Lett. 15, 093009 https://doi.org/ 10.1088/1748-9326/ab9be1.

Carlton, S.J., Jacobson, S.K., 2013. Climate change and coastal environmental risk perceptions in Florida. J. Environ. Manag. 130, 32-39. https://doi.org/10.1016/j. jenvman.2013.08.038.

Cash, D., Clark, W.C., Alcock, F., Dickson, N.M., Eckley, N., Jäger, J., 2003. Salience, Credibility, Legitimacy and Boundaries: Linking Research, Assessment and Decision Making (SSRN Scholarly Paper No. ID 372280). Social Science Research Network, Rochester, NY. https://doi.org/10.2139/ssrn.372280.

Cave, D., 2012. Digital Islands: How the Pacific ICT Revolution Is Transforming the Region. Lowy Institute For International Policy, Sydney, Australia.

Cermakian, J., Metton, A., Raveneau, J., 1970. Saint-Pierre-et-Miquelon. Les mutations d'une économie insulaire. Ann. Geograph. 79, 657-688. https://doi.org/10.3406/ geo.1970.15159.

Circé, M., Da Silva, L., Duff, G., Boyer-Villemaire, U., Corbeil, S., Desjarlais, C., Morneau, F., 2016. Analyse coûts-avantages des options d'adaptation en zone côtière aux Îles-de-la-Madeleine. (No. 540010- 000). Ouranos, Montréal.

Claude, G., Lavarde, P., Viora, M., Guespereau, M., 2015. Evaluation du plan national d'adaptation au changement climatique (No. 010178-01). CGEDD, Paris, France.

Collins, M., Sutherland, M., Bouwer, L., Cheong, S.-M., Frölicher, T., Jacot Des Combes, H., Koll Roxy, M., Losada, I.J., McInnes, K., Ratter, B., Swingedouw, D., Tibig, L., 2019. Extremes, abrupt changes and managing risk. In: Pörtner, H.-O., Roberts, D.C., Masson-Delmotte, V., Zhai, P., Tignor, M., Poloczanska, E., Mintenbeck, K., Alegría, A., Nicolai, M., Okem, A., Petzold, J., Rama, B., Weyer, N. M. (Eds.), IPCC Special Report on the Ocean and Cryosphere in a Changing Climate. In press, p. 68

Coquet, M., Mercier, D., Fleury-Bahi, G., 2018. Individuals' perceptions of areas exposed to coastal flooding in four French coastal municipalities: the contribution of sketch mapping. Geoenviron. Disasters 5, 22. https://doi.org/10.1186/s40677-018-0107-3.

Costas, S., Ferreira, O., Martinez, G., 2015. Why do we decide to live with risk at the coast? Ocean Coast Manag. 118, 1-11. https://doi.org/10.1016/j. ocecoaman.2015.05.015.

Côté, S., 1999. Les Ntic et le développement des régions: une réflexion à poursuivre. Can. Geogr./Le. Géogr. Can. 43, 126-133. https://doi.org/10.1111/j.1541-0064.1999. tb01368.x.

Creach, A., Bastidas-Arteaga, E., Pardo, S., Mercier, D., 2020. Vulnerability and costs of adaptation strategies for housing subjected to flood risks: application to La Guérinière France. Mar. Pol. 117, 23. https://doi.org/10.1016/j. marpol.2019.02.010.

De La Torre, Y., 2021. Erosion de l'isthme Miquelon-Langlade en Février et Mars 2021. Rapport d'expertise. Rapport BRGM/RP-70620-FR, p. 21.

De La Torre, Y., Douris, L., Bulteau, T., Garcin, M., Lecacheux, S., 2016. VULIT 2 Vulnérabilité du littoral de Saint-Pierre-et-Miquelon face aux risques côtiers. Phase 2 : caratérisation des aléas recul du trait de côte et submersion marine. (Rapport final No. BRGM/RP-63988-FR). BRGM.

De La Torre, Y., Falguière, S., Le Roy, M., 2013. VULIT SPM1 - Vulnérabilité du littoral de Saint Pierre et Miquelon face aux risques côtiers. Phase 1 : État des lieux de la dynamique côtière et des enjeux. (Rapport final No. BRGM/RP-62935-FR). BRGM.

Depraz, S., Laslaz, L., 2017. Conflicts, acceptance problems and participative policies in the national parks of the French Alps. J. Protected Mountain Areas Resear. Manag. 9, 46-56. https://doi.org/10.1553/eco.mont-9-sis46 special issue.

Devine-Wright, P., 2009. Rethinking NIMBYism: the role of place attachment and place identity in explaining place-protective action. J. Community Appl. Soc. Psychol. 19, 426-441. https://doi.org/10.1002/casp.1004.

Dillman, D.A., Smyth, J.D., Christian, L.M., 2014. Internet, Phone, Mail, and Mixed-Mode Surveys: the Tailored Design Method. John Wiley \& Sons.

Eisenack, K., Moser, S.C., Hoffmann, E., Klein, R.J.T., Oberlack, C., Pechan, A., Rotter, M., Termeer, C.J.A.M., 2014. Explaining and overcoming barriers to climate change adaptation. Nat. Clim. Change 4, 867-872. https://doi.org/10.1038/ nclimate 2350.

Ford, J.D., Couture, N., Bell, T., Clark, D.G., 2017. Climate change and Canada's north coast: research trends, progress, and future directions. Environ. Rev. 26, 82-92. https://doi.org/10.1139/er-2017-0027.

Fournis, Y., Fortin, M.-J., 2015. Une définition territoriale de l'acceptabilité sociale : pièges et défis conceptuels. [VertigO] La revue électronique en sciences de l'environnement 15, 18. https://doi.org/10.4000/vertigo.16682.

Friesinger, S., Bernatchez, P., 2010. Perceptions of Gulf of St. Lawrence coastal communities confronting environmental change: hazards and adaptation, Québec, Canada. Ocean Coast Manag. 53, 669-678. https://doi.org/10.1016/j. ocecoaman.2010.09.001.

Frippiat, D., Marquis, N., 2010. Les enquêtes par Internet en sciences sociales : un état des lieux, vol. 65. Institut national d'études démographiques -Population, pp. 309-338. https://doi.org/10.3917/popu.1002.0309.

Gibbs, M.T., 2016. Why is coastal retreat so hard to implement? Understanding the political risk of coastal adaptation pathways. Ocean Coast Manag. 130, 107-114. https://doi.org/10.1016/j.ocecoaman.2016.06.002.

Goeldner-Gianella, L., Bertrand, F., Oiry, A., Grancher, D., 2015. Depolderisation policy against coastal flooding and social acceptability on the French Atlantic coast: the case of the Arcachon Bay. Ocean Coast Manag. 116, 98-107. https://doi.org/ 10.1016/j.ocecoaman.2015.07.001.

Goeldner-Gianella, L., Grancher, D., Magnan, A.K., de Belizal, E., Duvat, V.K.E., 2019. The perception of climate-related coastal risks and environmental changes on the Rangiroa and Tikehau atolls, French Polynesia: the role of sensitive and intellectual drivers. Ocean Coast Manag. 172, 14-29. https://doi.org/10.1016/j. ocecoaman.2019.01.018. 
Haasnoot, M., Brown, S., Scussolini, P., Jimenez, J.A., Vafeidis, A.T., Nicholls, R.J., 2019. Generic adaptation pathways for coastal archetypes under uncertain sea-level rise. Environmental Research Communications 1, 12. https://doi.org/10.1088/2515$7620 / \mathrm{ab} 1871$.

Herman-Mercer, N.M., Matkin, E., Laituri, M.J., Toohey, R.C., Massey, M., Elder, K., Schuster, P.F., Mutter, E.A., 2016. Changing times, changing stories: generational differences in climate change perspectives from four remote indigenous communities in Subarctic Alaska. Ecol. Soc. 21, 28. https://doi.org/10.5751/ES-08463-210328.

IEDOM, 2017. Rapport Annuel 2018. Saint-Pierre-et-Miquelon. Institut d'Emission des Départements d'Outre-Mer, France.

INSEE, 2019. Populations légales en vigueur à compter du 1er janvier 2019. Communes de Saint-Pierre-et-Miquelon. INSEE, Paris.

Jodelet, D. (Ed.), 2003. Les Représentations Sociales, 7. Éd. Sociologie d'aujourd'hui. Presses Univ. de France, Paris.

Jones, N., Clark, J.R.A., 2014. Social capital and the public acceptability of climate change adaptation policies: a case study in Romney Marsh, UK. Climatic Change 123, 133-145. https://doi.org/10.1007/s10584-013-1049-0.

King, D., Bird, D., Haynes, K., Boon, H., Cottrell, A., Millar, J., Okada, T., Box, P., Keogh, D., Thomas, M., 2014. Voluntary relocation as an adaptation strategy to extreme weather events. International Journal of Disaster Risk Reduction 8, 83-90. https://doi.org/10.1016/j.ijdrr.2014.02.006.

Lambert, M.-L., 2015. Le recul stratégique : de l'anticipation nécessaire aux innovations juridiques. VertigO - la revue électronique en sciences de l'environnement Horssérie. https://doi.org/10.4000/vertigo.15812 [Online].

Lammel, A., Guillen Gutierrez, E., Dugas, E., Jamet, F., 2013. Cultural and environmental changes : cognitive adaptation to global warming. In: Streering the Cultural Dynamics. Presented at the Congress of the International Association for CrossCultural Psychology, pp. 49-58. Melbourne.

Larsen, J.N., Anisimov, O.A., Constable, A., Hollowed, A.B., Maynard, N., Prestrud, P., Prowse, T.D., Stone, J.M.R., 2014. Polar regions. In: Barros, V.R., Field, C.B. Dokken, D.J., Mastrandrea, M.D., Mach, K.J., Bilir, T.E., Chatterjee, M., Ebi, K.L., Estrada, Y.O., Genova, R.C., Girma, B., Kissel, E.S., Levy, A.N., MacCracken, S., Mastrandrea, P.R., White, L.L. (Eds.), Climate Change 2014: Impacts, Adaptation, and Vulnerability. Part B: Regional Aspects. Contribution of Working Group II to the Fifth Assessment Report of the Intergovernmental Panel on Climate Change. Cambridge University Press, Cambridge, United Kingdom and New York, NY, USA, pp. 1567-1612.

Lata, S., Nunn, P., 2012. Misperceptions of climate-change risk as barriers to climatechange adaptation: a case study from the Rewa Delta, Fiji. Climatic Change 110, 169-186. https://doi.org/10.1007/s10584-011-0062-4.

Lawrence, J., Quade, D., Becker, J., 2014. Integrating the effects of flood experience on risk perception with responses to changing climate risk. Nat. Hazards 74, 1773-1794. https://doi.org/10.1007/s11069-014-1288-z.

Le Gléau, J.-P., Castaing, D., 2000. Le recensement de la population à Saint-Pierre-etMiquelon, vol. 4p. INSEE Première.

Lee, T.M., Markowitz, E.M., Howe, P.D., Ko, C.-Y., Leiserowitz, A.A., 2015. Predictors of public climate change awareness and risk perception around the world. Nat. Clim. Change 5, 1014-1020. https://doi.org/10.1038/nclimate2728.

Lemmen, D.S., Warren, F.J., James, T., Mercer Clarke, C.S.L., 2016. Le littoral maritime du Canada face à l'évolution du climat. Gouvernement du Canada, Ottawa (Ontario), p. 280 .

Magnan, A.K., Garschagen, M., Gattuso, J.-P., Hay, J.E., Hilmi, N., Holland, E., Isla, F., Kofinas, G., Losada, I.J., Petzold, J., Ratter, B., Schuur, T., Tabe, T., Van de Wal, R., 2019. Cross-chapter box 9: integrative cross-chapter box on low-lying islands and coasts. In: Roberts, D.C., Masson-Delmotte, V., Zhai, P., Tignor, M., Poloczanska, E., Mintenbeck, K., Alegría, A., Nicolai, M., Okem, A., Petzold, J., Rama, B., Weyer, N. M. (Eds.), IPCC Special Report on the Ocean and Cryosphere in a Changing Climate [H.-O. Pörtner. In press, p. 18.

Measham, T.G., Preston, B.L., Smith, T.F., Brooke, C., Gorddard, R., Withycombe, G., Morrison, C., 2011. Adapting to climate change through local municipal planning: barriers and challenges. Mitig. Adapt. Strategies Glob. Change 16, 889-909. https:// doi.org/10.1007/s11027-011-9301-2.

Meredith, M., Sommerkorn, M., Casotta, S., Derksen, C., Ekaykin, A., Hollowed, A.B., Kofinas, G., Mackintosh, A., Melbourne-Thomas, J., Muelbert, M.M., Ottersen, G., Pritchard, H., Schuur, E.A.G., 2019. Chapter 3: polar regions. In: Pörtner, H.-O., Roberts, D.C., Masson-Delmotte, V., Zhai, P., Tignor, M., Poloczanska, E., Mintenbeck, K., Alegría, A., Nicolai, M., Okem, A., Petzold, J., Rama, B., Weyer, N. M. (Eds.), IPCC Special Report on the Ocean and Cryosphere in a Changing Climate, p. 118p.

Mimura, N., Pulwarty, R.S., Duc, D.M., Elshinnawy, I., Sanchez-Rodriguez, R.A., 2014. Chapter 15: adaptation planning and implementation. In: Field, C.B., Barros, V.R., Dokken, D.J., Mach, K.J., Mastrandrea, M.D., Bilir, T.E., Chatterjee, M., Ebi, K.L., Estrada, Y.O., Genova, R.C., Girma, B., Kissel, E.S., Levy, A.N., MacCracken, S., Mastrandrea, P.R., White, L.L. (Eds.), Climate Change 2014: Impacts, Adaptation, and Vulnerability. Part A: Global and Sectoral Aspects. Contribution of Working Group II to the Fifth Assessment Report of the Intergovernmental Panel on Climate Change. Cambridge University Press, Cambridge, United Kingdom and New York, NY, USA, pp. 869-898.

Minéo-Kleiner, L., 2017. L'option de la relocalisation des activités et des biens face aux risques côtiers : stratégies et enjeux territoriaux en France et au Québec. (Doctorat en Géographie). Université de Bretagne Occidentale, Brest, p. 350.

Muttarak, R., Lutz, W., 2014. Is education a key to reducing vulnerability to natural disasters and hence unavoidable climate change? Ecol. Soc. 19 https://doi.org/ 10.5751/ES-06476-190142 art42.
Morris, R.L., Konlechner, T.M., Ghisalberti, M., Swearer, S.E., 2018. From grey to green: efficacy of eco-engineering solutions for nature-based coastal defence. Global Change Biol. 24, 1827-1842. https://doi.org/10.1111/gcb.14063.

Neumann, B., Vafeidis, A.T., Zimmermann, J., Nicholls, R.J., 2015. Future coastal population growth and exposure to sea-level rise and coastal flooding - a global assessment. PLoS One 10, 34. https://doi.org/10.1371/journal.pone.0118571.

Noble, I.R., Huq, S., Anokhin, Y.A., Carmin, J., Goudou, D., Lansigan, F.P., OsmanElasha, B., Villamizar, A., 2014. Adaptation needs and options. In: Field, C.B., Barros, V.R., Dokken, D.J., Mach, K.J., Mastrandrea, M.D., Bilir, T.E., Chatterjee, M., Ebi, K.L., Estrada, Y.O., Genova, R.C., Girma, B., Kissel, E.S., Levy, A.N., MacCracken, S., Mastrandrea, P.R., White, L.L. (Eds.), Climate Change 2014: Impacts, Adaptation, and Vulnerability. Part A: Global and Sectoral Aspects. Contribution of Working Group II to the Fifth Assessment Report of the Intergovernmental Panel on Climate Change. Cambridge University Press, United Kingdom and New York, NY, USA, pp. 833-868.

Nurse, L., McLean, R., Agard, J., Briguglio, L., Duvat-Magnan, V., Pelesikoti, N., Tompkins, E.L., Webb, A., 2014. Small islands. In: Barros, V.R., Field, C.B., Dokken, D.J., Mastrandrea, M.D., Mach, K.J., Bilir, T.E., Chatterjee, M., Ebi, K.L., Estrada, Y.O., Genova, R.C., Girma, B., Kissel, E.S., Levy, A.N., MacCracken, S., Mastrandrea, P.R., White, L.L. (Eds.), Climate Change 2014: Impacts, Adaptation, and Vulnerability. Part B: Regional Aspects. Contribution of Working Group II to the Fifth Assessment Report of the Intergovernmental Panel on Climate Change. Cambridge University Press, Cambridge, United Kingdom and New York, NY, USA, pp. 1613-1654.

O'Connor, R.E., Bard, R.J., Fisher, A., 1999. Risk perceptions, general environmental beliefs, and willingness to address climate change. Risk Anal. 19, 461-471. https:// doi.org/10.1111/j.1539-6924.1999.tb00421.x.

Oiry, A., Grancher, D., 2019. Le milieu scolaire : un terrain privilégié de l'enseignement et/ou de l'éducation aux risques naturels dans les territoires d'outre-mer. Cah. Outre Mer. 72, 567-598. https://doi.org/10.4000/com.10693.

O'Neill, E., Brereton, F., Shahumyan, H., Clinch, J.P., 2016. The impact of perceived flood exposure on flood-risk perception: the role of distance. Risk Anal. 36, 2158-2186. https://doi.org/10.1111/risa.12597.

Oppenheimer, M., Glavovic, B.C., Hinkel, J., Van de Wal, R., Magnan, A.K., AbdElgawad, A., Cai, R., Cifuentes-Jara, M., DeConto, R., Gosh, T., Hay, J.E., Isla, F., Marzeion, B., Meyssignac, B., Sebesvari, Z., 2019. Sea level rise and implications for low-lying islands, coasts and communities. In: Roberts, D.C., Masson-Delmotte, V., Zhai, P., Tignor, M., Poloczanska, E., Mintenbeck, K., Alegría, A., Nicolai, M., Okem, A., Petzold, J., Rama, B., Weyer, N.M. (Eds.), IPCC Special Report on the Ocean and Cryosphere in a Changing Climate [H.-O. Pörtner, In Press, p. 126.

Osberghaus, D., Finkel, E., Pohl, M., 2010. Individual Adaptation to Climate Change: the Role of Information and Perceived Risk. ZEW - Centre for European Economic Research Discussion Paper. https://doi.org/10.2139/ssrn.1674840. Social Science Research Network 36.

Petzold, J., Magnan, A.K., 2019. Climate change: thinking small islands beyond small island developing states (SIDS). Climatic Change 152, 145-165. https://doi.org/ 10.1007/s10584-018-2363-3.

Raufflet, E., 2014. De l'acceptabilité sociale au développement local résilient. [VertigO] La revue électronique en sciences de l'environnement 14. https://doi.org/10.4000/ vertigo.15139 [Online].

Renn, O., 1998. The role of risk perception for risk management. Reliability Eng. Syst. Saf., Risk Perception Versus Risk Anal. 59, 49-62. https://doi.org/10.1016/S09518320(97)00119-1.

Rey-Valette, H., Rocle, N., Vye, D., Mineo-Kleiner, L., Longépée, E., Bazart, C., Lautrédou-Audouy, N., 2019. Acceptabilité sociale des mesures d'adaptation au changement climatique en zones côtières : une revue de dix enquêtes menées en France métropolitaine. VertigO - la Rev. Électr. En Sci. De L’Environ. 19 https://doi. org/10.4000/vertigo.26537 [Online].

Riviere-Honegger, A., Cottet, M., Morandi, B., 2015. Connaître les perceptions et les représentations : quels apports pour la gestion des milieux aquatiques. ONEMA 1-180. Comprendre pour agir.

Rocle, N., Rey-Valette, H., Bertrand, F., Becu, N., Long, N., Bazart, C., Vye, D., MeurFerec, C., Beck, E., Amalric, M., Lautrédou-Audouy, N., 2020. Paving the way to coastal adaptation pathways: an interdisciplinary approach based on territorial archetypes. Environ. Sci. Pol. 110, 34-45. https://doi.org/10.1016/j. envsci.2020.05.003.

Romero-Lankao, P., Smith, J.B., Davidson, D., Diffenbaugh, N., Kinney, P., Kirshen, P. Kovacs, P., Villiez-Ruiz, L., 2014. North America. In: Barros, V.R., Field, C.B., Dokken, D.J., Mastrandrea, M.D., Mach, K.J., Bilir, T.E., Chatterjee, M., Ebi, K.L., Estrada, Y.O., Genova, R.C., Girma, B., Kissel, E.S., Levy, A.N., MacCracken, S., Mastrandrea, P.R., White, L.L. (Eds.), Climate Change 2014: Impacts, Adaptation, and Vulnerability. Part B: Regional Aspects. Contribution of Working Group II to the Fifth Assessment Report of the Intergovernmental Panel on Climate Change. Cambridge University Press, Cambridge, United Kingdom and New York, NY, USA, pp. 1439-1498.

Shao, W., Goidel, K., 2016. Seeing is believing? An examination of perceptions of local weather conditions and climate change among residents in the U.S. Gulf Coast. Risk Anal. 36, 2136-2157. https://doi.org/10.1111/risa.12571.

Stephens, S.A., Bell, R.G., Lawrence, J., 2018. Developing signals to trigger adaptation to sea-level rise. Environ. Res. Lett. 13, 104004. https://doi.org/10.1088/1748-9326/ aadf96.

Taylor, A., Bruin, W.B. de, Dessai, S., 2014. Climate change beliefs and perceptions of weather-related changes in the United Kingdom. Risk Anal. 34, 1995-2004. https:// doi.org/10.1111/risa.12234.

Terorotua, H., Duvat, V.K.E., Maspataud, A., Ouriqua, J., 2020. Assessing perception of climate change by representatives of public authorities and designing Coastal 
Climate Services: lessons learnt from French Polynesia. Front. Mar. Sci. 7, 16. https://doi.org/10.3389/fmars.2020.00160.

Thistlethwaite, J., Henstra, D., Brown, C., Scott, D., 2018. How flood experience and risk perception influences protective actions and behaviours among Canadian homeowners. Environ. Manag. 61, 197-208. https://doi.org/10.1007/s00267-0170969-2.

Vasseur, L., Thornbush, M., Plante, S., 2017. Climatic and environmental changes affecting communities in atlantic Canada. Sustainability 9, 1293. https://doi.org/ 10.3390/su9081293.

Waters, E., Barnett, J., Puleston, A., 2014. Contrasting perspectives on barriers to adaptation in Australian climate change policy. Climatic Change 124, 691-702. https://doi.org/10.1007/s10584-014-1138-8.
Weber, E.U., 2016. What shapes perceptions of climate change? New research since 2010. WIREs Climate Change 7, 125-134. https://doi.org/10.1002/wcc.377.

Wong, P.P., Lasoda, I.J., Gattuso, J.-P., Hinkel, J., Khattabi, A., McInnes, K.L., Saito, Y., Sallenger, A., 2014. Coastal systems and low-lying areas. In: Field, C.B., Barros, V.R., Dokken, D.J., Mach, K.J., Mastrandrea, M.D., Bilir, T.E., Chatterjee, M., Ebi, K.L., Estrada, Y.O., Genova, R.C., Girma, B., Kissel, E.S., Levy, A.N., MacCracken, S., Mastrandrea, P.R., White, L.L. (Eds.), Climate Change 2014: Impacts, Adaptation, and Vulnerability. Part A: Global and Sectoral Aspects. Contribution of Working Group II to the Fifth Assessment Report of the Intergovernmental Panel on Climate Change. Cambridge University Press, Cambridge, United Kingdom and New York, NY, USA, pp. 361-409. 